\title{
Tiarei marginal sites: Sites M0008, M0010-M0014, and M0022
}

\author{
Expedition 310 Scientists $^{2}$
}

\begin{abstract}
Chapter contents
Operations............... 1

Sedimentology and biological assemblages. . . 2

Petrophysics ...............

Geochemistry ................

References.................. 9

Figures................... 10

Table ...................... 31
\end{abstract}

\footnotetext{
${ }^{1}$ Expedition 310 Scientists, 2007. Tiarei marginal sites: Sites M0008, M0010-M0014, and M0022. In Camoin, G.F., Iryu, Y., Mclnroy, D.B., and the Expedition 310 Scientists. Proc. IODP, 310: Washington, DC (Integrated Ocean Drilling Program Management International, Inc.). doi:10.2204/iodp.proc.310.109.2007

'Expedition 310 Scientists' addresses.
}

\section{Operations \\ Hole M0008A}

At $1700 \mathrm{~h}$ on 16 October 2005, the DP Hunter departed Site M0007 and headed for Site M0008, located on transect TAH-02A off the northeast coast of Tahiti.

Shortly after arrival at $2400 \mathrm{~h}$, a seabed survey using the downpipe camera was conducted. At $0400 \mathrm{~h}$ on 17 October, coring operations began in Hole M0008A. This hole was to serve as a reference hole for the other holes on the transect. However, recovered material consisted of river deposits of unconsolidated basalt gravels and pebbles mixed with volcaniclastic sediments. As a result, recovery was poor throughout (24.5\%). Total depth (TD) was reached at 40.2 meters below seafloor (mbsf), and operations ended in Hole M0008A at $1720 \mathrm{~h}$ on 17 October.

Before continuing operations at Tiarei marginal sites, operations were conducted at Site M0009 (see the "Tiarei outer ridge" chapter).

\section{Hole M0010A}

The DP Hunter was positioned above Hole M0010A by $1400 \mathrm{~h}$ on 22 October 2005, $\sim 140 \mathrm{~m}$ east-southeast of proposed Site TAH02A 4, in $89.53 \mathrm{~m}$ water depth. Seacore's drilling and reentry template (DART) was drilled into the seabed, and coring operations began at $1635 \mathrm{~h}$. Coring continued until $1000 \mathrm{~h}$ on 23 October, to a TD of 34.6 mbsf. During the coring period, an HQ string trip was made to clear a continually blocking bit.

\section{Hole M0011A}

Hole M0011A was located $\sim 140 \mathrm{~m}$ east of proposed Site TAH-02A 4 , in $101.34 \mathrm{~m}$ water depth. After running the American Petroleum Institute (API) pipe, drilling the DART into the seabed, and running the HQ pipe, coring operations began at $1330 \mathrm{~h}$ on 23 October 2005. Coring commenced in very soft silts with poor recovery, but recovery improved when the river deposits gave way to a carbonate framework. At $0030 \mathrm{~h}$ on 24 October, coring operations were completed in Hole M0011A at a depth of 17.65 mbsf.

\section{Hole M0012A}

Hole M0012A was the first of three holes to be located within the new Environmental Protection and Safety Panel (EPSP)-approved 
zone southeast of proposed Site TAH-02A 4. Before the DART was lowered onto the seabed, a downpipe camera survey was run; it showed a live coral colony at the first location. The ship was repositioned $25 \mathrm{~m}$ downslope in $77.05 \mathrm{~m}$ water depth, and the DART was drilled in. Coring operations began in Hole M0012A at $0900 \mathrm{~h}$ on 24 October 2005. Recovery was generally poor, although it improved in the more competent material at the base of the hole. Coring was completed at $2040 \mathrm{~h}$ on 24 October at a TD of 34.1 mbsf.

\section{Hole M0013A}

Hole M0013A was located $30 \mathrm{~m}$ downslope from Hole M0012A, in $90.95 \mathrm{~m}$ water depth. The DP Hunter was in position to start drilling at $2300 \mathrm{~h}$ on 24 October 2005. After the API pipe and DART were lowered to the seabed, a downpipe camera survey was conducted. Coring operations began at $0100 \mathrm{~h}$ on 25 October. At $0415 \mathrm{~h}$, coring was abandoned because of the lack of suitable coral material. TD was 11.7 mbsf.

\section{Hole M0014A}

Hole M0014A was spudded $~ 70 \mathrm{~m}$ north-northwest of Hole M0013A, in $99.25 \mathrm{~m}$ water depth. Coring operations began at $0610 \mathrm{~h}$ on 25 October 2005 and were completed at $1615 \mathrm{~h}$ at a TD of $15.43 \mathrm{mbsf}$. The HQ string, API pipe, and DART were lifted onto deck and secured for the transit to previous Site M0007 at the south end of the island.

Poor weather was forecast for north of the island, and so the decision was made to revisit promising sites in the south. The transit commenced at $1930 \mathrm{~h}$, and Site M0007 was reached at $0200 \mathrm{~h}$ on 26 October. Operations recommenced at Site M0007 (see the "Maraa western transect" chapter), followed by operations at Sites M0015-M0018 (see the "Maraa eastern transect" chapter). After operations in the Maraa area were completed, operations were conducted at Sites M0019 and M0020 (see the "Faaa" chapter). On returning to the Tiarei area, operations were conducted at new Site M0021 and previous Site M0009 (see the "Tiarei outer ridge" chapter). Operations at new Site M0022 followed.

\section{Hole M0022A}

The DP Hunter was positioned above Hole M0022A, $\sim 175 \mathrm{~m}$ north-northwest of proposed Site TAH-02A 4 , in $115 \mathrm{~m}$ water depth. After checking the depth with the tautwire, the DART was drilled in and coring commenced at $1750 \mathrm{~h}$ on 9 November 2005. It was hoped that the hole would penetrate a Pleistocene gully that may have been subsequently ac- creted by last deglacial corals. Basalt gravel and volcaniclastic sand of Pleistocene affinity were recovered from a shallow depth, so Hole M0022A was abandoned after $8.8 \mathrm{~m}$ penetration at $2310 \mathrm{~h}$ on 9 November. By midnight, preparations were being made to trip the API pipe and DART.

At $0000 \mathrm{~h}$ on 10 November, the DART was raised to the moonpool after abandoning coring in Hole M0022A, and the vessel was moved to previous Site M0023 (see the "Tiarei inner ridge" chapter).

\section{Sedimentology and biological assemblages}

\section{Holes dominated by volcaniclastic sediments}

\section{Hole M0008A}

Hole M0008A contains a $35.90 \mathrm{~m}$ thick sequence, from 64.15 to 100.05 meters below sea level (mbsl), and includes two lithologic subunits composed of volcaniclastic sediments.

\section{Subunit $A$}

Interval: Core 310-M0008A-1R through Section 10R-1

Volcaniclastic Subunit A is black uncemented to poorly consolidated volcaniclastic sand, silt, and clay interlayered with beds of variable thickness that are composed of basalt pebbles, cobbles, and boulders (Fig. F1) (e.g., interval 310-M0008A-8R-1, 80-110 $\mathrm{cm}$ ) with a granule-rich sandstone/siltstone subunit member in Section 310-M0008A-8R-CC. At the top of the underlying Section 310-M0008A-7R-CC is a thin $(\sim 4 \mathrm{~cm}$ thick) granule conglomerate horizon, underlain by a rubble interval.

Sand and silt are unsorted and not graded; clay and subrounded granules are subordinate. They include volcanic lithics, feldspars, feldspathoids, quartz, and iron oxides and hydroxides. Skeletal components include foraminifers and fragments of corals (acroporids), mollusks, echinoids, and Halimeda; in situ roots occur locally.

The sand/silt sediment in the upper section of the hole is generally gray in color, whereas that in the lower part is orange (10-15 cm horizon transition in Section 310-M0008A-8R-1, $100 \mathrm{~cm}$ ). (Note that a similar color transition was observed in the bindstone unit in Section 310-M0021B-19R-1.) The transition from gray to orange is interpreted as the result of a change in the relative proportions of iron oxides/oxyhydroxides with the possible increase in decayed organic matter; brownish color is locally conspicuous. The amount of clays (mud) also increases 
downward, peaking at the bottom of Section 310M0008A-16R-1, where the lithology turns to a silty clay (mud) subunit. A large boulder (or lava flow?) is present in the rubble unit from Section 310M0008A-7R-CC to Section 8R-1, $80 \mathrm{~cm}$, above the gray to orange color transition.

Pebbles, cobbles, and boulders are subangular to rounded and mostly composed of a slightly to moderately altered basalt, sparsely to highly phyric, nonvesicular to sparsely vesicular, with olivine, pyroxene, and feldspars; some subangular pebbles are made of siltstone to very coarse sandstone that includes volcanic lithics, iron oxides and hydroxides, and skeletal grains. Some pebbles and cobbles are encrusted with coralline algae.

\section{Subunit B}

Interval: Cores 310-M0008A-10R-1 through 19R

Volcaniclastic Subunit B is black, dark brown, to reddish brown and orange volcaniclastic siltstone to sandstone interlayered with volcaniclastic sand and silt and volcaniclastic cobble and rubble.

Siltstone and sandstone are massive, weakly cemented, unsorted, and not graded; they usually exhibit weak and irregular stratifications. They are mostly composed of angular to subangular grains including volcanic lithics, feldspars, feldspathoids, quartz, iron oxides and hydroxides, and skeletal grains (coral fragments, tiny mollusks, and algal fragments). Organic-rich soil horizons occur in Sections 310-M0008A-14R-1 and 15R-1.

Rubble is made of angular to subrounded basalt granules and pebbles, whereas basalt comprises angular basalt cobbles. A few small (approximately a few millimeters to a centimeter in length) wood fragments and rare, delicate, fine (submillimeter diameter) roots are present in the sand/silt units.

\section{Hole M0022A}

Interval: Cores 310-M0022A-1R through 6R

A $7 \mathrm{~m}$ thick sequence (118.64-125.46 mbsl) of volcanic granules and pebbles, including a mediumgrained trachyandesite or mugearite, and fragments of corals (branching Pocillopora) was recovered in Hole M0022A overlying volcanic siltstone (Sections $310-\mathrm{M} 0022 \mathrm{~A}-12 \mathrm{R}-1,12 \mathrm{~cm}$, to 3R-1) that includes subangular to subrounded pebbles of fine- to medium-grained basalt rich in olivine, pyroxene, and feldspars and of medium-grained andesite or mugearite (Fig. F2) (e.g., interval 310-M0022A-2R-1, $23-33 \mathrm{~cm}$ ). Volcanic siltstone includes skeletal grains and exhibit bioturbation; their tops are encrusted with coralline algae in Core 310-M0022A-2R. A bio- clast/basalt conglomerate unit (interval 310M0022A-4R-1, 0-23 cm) and a volcanic siltstone unit compose the bottom of the hole.

\section{Holes composed of volcaniclastic sediments and carbonates}

\section{Last deglacial sequence (Unit I)}

In holes near the outer ridge (Holes M0010AM0014A), the last deglacial sequence (lithologic Unit I) is composed of three successive subunits that were recovered from 78.85 to $117 \mathrm{mbsl}$.

\section{Subunit IA}

Interval: Cores 310-M0012A-1R through 16R

Lithologic Subunit IA was recovered only at Site M0012 from 78.85 to 107 mbsl. It is mostly composed of loose sediments (coral rubble and skeletal silt and sand) locally interlayered with volcaniclastic sand rich in skeletal grains.

Coral rubble consists mostly of gravels, pebbles, and cobbles of coral fragments (foliaceous and encrusting Pavona, Leptoseris, Montipora, and Pachyseris and branching Pocillopora and Porites), crusts of nongeniculate coralline algae, microbial crusts, and clasts of coralgal-microbialite frameworks. Those elements are generally well rounded to subangular and display abundant traces of bioerosion. Fragments of bivalves and gastropods and Halimeda segments also occur. Sand-sized volcanic grains are locally associated. Basalt cobbles and smaller pebbles and granules are prevalent rubble components in Sections 310M0012A-13R-1 and 14R-1.

Skeletal silt to sand is composed of fragments of corals, coralline and green (especially Halimeda) algae, and, to a lesser extent, bryozoans, mollusks, and foraminifers (Amphistegina and Heterostegina).

In situ coral colonies occur in Section 310-M0012A9R-1 (massive Porites), Core 14R (encrusting Montipora), and Section 15R-1 (robust branching Pocillopora) (Fig. F3) (e.g., interval 15R-1, 17-40 cm).

\section{Subunit IB}

Intervals: Cores 310-M0010A-1R through 4R, 310M0011A-1R and 2R, 310-M0012A-7R and 8R, 310-M0013A-1R through 5R, and 310M0014A-1R through 3R

Lithologic Subunit IB, recovered in an interval ranging generally from 90 to $100-105 \mathrm{mbsl}$, is dominated by volcaniclastic sediments that are locally interlayered with beds composed of carbonate elements, including coral colonies. The various lithologies recovered follow. 


\section{Volcaniclastic and skeletal sand/silt}

Volcaniclastic and skeletal sand and silt usually form the top of the recovered sequences. Skeletal grains are abundant and include Halimeda segments, benthic and planktonic foraminifers, and mollusk fragments. This unit includes beds composed of angular to subangular gravels, pebbles, and cobbles of fine- to medium-grained phyric or vesicular basalt that includes fine laths of feldspathoids and pyroxenes; the groundmass is aphanitic. Alteration of the basalt is variable.

The top $\sim 8 \mathrm{~m}$ in Hole M0010A (Sections 310M00010A-1R-1 through 4R-CC) consists of unconsolidated volcanic sand and silt. The amount and size of lithic basalt and coral debris components increase downward. Basalt cobbles and pebbles were observed in the rubble unit in the upper part of Hole M0011A (from Section 310-M0011A-1R-1 to Section 3R-CC). Thin volcanic sand units appear near the upper part (Sections 310-M0012A-7R-CC and 8R-CC) of Hole M0012A. Rubble at the top of Hole M0013A contains basalt pebbles. This unit is underlain by a volcanic sand/silt unit. A volcanic silt unit occupies the upper part of Hole M0014A (Section 310M0014A-1R-1 and interval 2R-1, 0-11 cm).

\section{Carbonate and volcanic beds}

Beds are composed of a mixture of carbonate and volcanic elements. Carbonate rubble is mostly composed of coral fragments, pieces of coralline algal crusts, and pebble-sized clasts of microbialite-coralgal frameworks. Coral fragments include robust branching Pocillopora and Acropora, branching Porites, and encrusting Montipora and Pachyseris, some of which are encrusted with coralline algae and/or microbialites (dense and thrombolitic microbial fabrics). Volcanic elements include cobble- and pebble-sized pieces of basalt.

\section{Subunit IC}

Intervals: Cores 310-M0010A-5R through 9R, 310M0011A-2R through 9R, and 310-M0014A$3 \mathrm{R}$ through $12 \mathrm{R}$

Lithologic Subunit IC, from 100 to $115 \mathrm{mbsl}$, is primarily composed of coralgal-microbialite frameworks interlayered with beds composed of

- Coral rubble and fragments of coralline algal crusts and microbialites mixed with sand- to pebble-sized volcanic elements,

- Skeletal sand rich in Halimeda segments, foraminifers, and fragments of mollusks and coralline algae mixed with volcanic grains, and

- Volcaniclastic and skeletal sand and silt.
Frameworks are composed of distinctive coral assemblages dominated by branching colonies of Pocillopora, Acropora, Porites, and Montipora, encrusting colonies of Montipora, agariciids, and faviids (including Leptastrea), and massive colonies of Porites and faviids.

\section{Encrusting colonies}

Intervals: Cores 310-M0010A-7R and 8R, 310M0011A-6R through 9R, and 310-M0014A$5 \mathrm{R}, 9 \mathrm{R}, 11 \mathrm{R}$, and $12 \mathrm{R}$

This interval comprises encrusting Montipora, agariciids, and faviids and branching Porites (Fig. F4) (e.g., interval 310-M0011A-7R-1, 10-21 cm). These corals are coated with thin nongeniculate coralline algal crusts and microbialites (especially thrombolites) to form a loose framework. Primary cavities are partially filled with skeletal sand and gravels, including abundant volcanic components.

\section{Massive colonies}

Intervals: Cores 310-M0010A-9R, 310-M0011A-2R, $4 \mathrm{R}$, and $6 \mathrm{R}$, and 310-M0014A-3R, 5R through $7 \mathrm{R}$, and $10 \mathrm{R}$

Massive colonies of Porites and faviids are locally associated with branching Pocillopora and Montipora. Some massive colonies of Porites are as thick as 50 $\mathrm{cm}$. Microbialites may form dense compact layers overlying thin crusts of nongeniculate coralline algae in those frameworks. Some primary cavities in the frameworks are infilled with volcaniclastic sediments.

\section{Older Pleistocene sequence (Unit II)}

The boundary between the last deglacial and the older Pleistocene sequences is sharp and was recovered in Holes M0011A (interval 310-M0011A-9R-1, 1 cm; Fig. F5), M0012A (interval 310-M0012A-16R-1, $30 \mathrm{~cm}$; Fig. F6), and M0014A (interval 310-M0014A$13 \mathrm{R}-1,45 \mathrm{~cm}$ ).

Lithologic Unit II is composed of well-lithified gray to light brown coralgal boundstone, coral rudstone, and skeletal sandy limestone interlayered locally with horizons of gravels and rubbles made of that material. Coral assemblages are dominated by foliaceous colonies of Pachyseris, tabular and branching colonies of Acropora, robust branching Pocillopora, encrusting and branching colonies of Montipora, and branching and massive colonies of Porites. Microbialites are abundant and include laminated and thrombolitic fabrics. The matrix of the limestone is rich in Halimeda segments; volcanic grains are locally abundant. Subaerial diagenetic processes are indicated by the alteration of coral skeletons and the 
occurrence of large solution cavities filled with volcaniclastic and skeletal sandstone and with gravels and rubble, including fragments of branching Pocillopora and basalt pebbles at the top of the sequence.

In Hole M0014A, the base of the older Pleistocene sequence is composed of sandy skeletal grainstone rich in Halimeda segments, shell fragments, and much less common bryozoan skeletons; fine to medium sand-sized volcanic grains are commonly associated (Figs. F7, F8) (e.g., intervals 310-M0014A-13R-1, 26$60 \mathrm{~cm}$, and 13R-1, 105-115 cm). This unit grades downward into poorly bedded volcaniclastic sandstone rich in skeletal grains (Halimeda and corals associated with foraminifers, bryozoans, and gastropods). A volcanic cobble occurs in a coral mudstone unit in Section 310-M0014A-13R-1.

\section{Petrophysics}

Recovery at Tiarei marginal sites, on the northeastern side of the island of Tahiti, was mostly low (Hole M0008A $=24 \%$, Fig. F9; Hole M0010A $=30 \%$, Fig. F10; Hole M0012A = 25\%, Fig. F11; Hole M0013A = 11\%, Fig. F12) and partial (Hole M0011A = 49\%, Fig. F13; Hole M0014A = 46\%, Fig. F14; Hole M0022A = 57\%, Fig. F15). Cores 310-M0010A-1R, 2R, 3R, and 10R, 310-M0012A-2R, 310-M0013A-3R, 310M0014A-5R, 6R, and 10R, and 310-M0022A-2R, 3R, and $4 \mathrm{R}$ were left unsaturated and therefore have different data coverage and quality (see the "Methods" chapter for more details). Water depths are as follows: Hole M0008A = 62.65 mbsf, Hole M0010A = $89.53 \mathrm{mbsl}$, Hole M0011A $=101.34 \mathrm{mbsl}$, Hole M0012A $=77.05 \mathrm{mbsl}$, Hole M0013A $=90.55 \mathrm{mbsl}$, Hole M0014A $=99.25$ mbsl, Hole M0022A $=117.54$ mbsl.

The units recovered from these sites are dominated by volcaniclastic clay and sand and basalt gravels, pebbles, and cobbles; the last deglacial sequence (lithologic Unit I) is closely associated and interlayered with volcaniclastic sediments; the older Pleistocene sequence (lithologic Unit II) comprises coralgal skeletal sandy limestone locally abundant in volcanic grains.

As recovery was generally low and recovered intervals were often disturbed by drilling or left unsaturated because of the un- to semilithified character of the deposits, MSCL observations are highly discontinuous. No discrete sample measurements are available for Holes M0008A and M0013A (Figs. F9, F12).

\section{Density and porosity}

Bulk density at Tiarei marginal sites was measured with gamma ray attenuation (GRA) on the MSCL and on discrete samples (MAD). Hole M0008A (Fig. F9) only recovered volcaniclastic sediments and basalt (see "Sedimentology and biological assemblages"). Volcaniclastic sands were semilithified and have low densities of $\sim 1.8 \mathrm{~g} / \mathrm{cm}^{3}$. The one basalt section cored, however, has a high density of $3.0 \mathrm{~g} / \mathrm{cm}^{3}$. Porosity calculations reveal high porosities up to $60 \%$ for volcaniclastic sands. This has to be interpreted with care, however, because porosity is calculated using a constant grain density of calcium carbonate: $2.71 \mathrm{~g} / \mathrm{cm}^{3}$. The basalt section is very low in porosity and records values near zero.

At Sites M0010-M0014, the last deglacial and older Pleistocene sequences are composed of reef rocks with interbedded volcaniclastic sediments. Densities for the last deglacial interval are variable but concentrate around $2.0 \mathrm{~g} / \mathrm{cm}^{3}$ with a minimum of $\sim 1.8 \mathrm{~g} /$ $\mathrm{cm}^{3}$ and a maximum of $2.2 \mathrm{~g} / \mathrm{cm}^{3}$. The older Pleistocene sequence is characterized by a step increase in density toward an average value of $\sim 2.2 \mathrm{~g} / \mathrm{cm}^{3}$. Densities in this interval are variable but are generally $>2.0 \mathrm{~g} / \mathrm{cm}^{3}$ and are never $>2.4 \mathrm{~g} / \mathrm{cm}^{3}$. Porosity in both intervals ranges between $20 \%$ and $45 \%$, but is $\sim 30 \%$ on average. Grain density averages $2.76 \mathrm{~g} / \mathrm{cm}^{3}$, and MAD values range from 1.87 to $2.46 \mathrm{~g} / \mathrm{cm}^{3}$ with two unreliable outliers of $1.43 \mathrm{~g} / \mathrm{cm}^{3}$ (Hole M0012A; $30.17 \mathrm{mbsf}$ ) and $3.9 \mathrm{~g} / \mathrm{cm}^{3}$ (Hole M0012A, 29.89 mbsf; Fig. F11).

In Hole M0022A, mainly volcaniclastic sediments were recovered, which show consistent density values of $2.2 \mathrm{~g} / \mathrm{cm}^{3}$. Porosity is $30 \%$ overall but ranges from $20 \%$ to $45 \%$. Discrete density measurements range from 2.90 to $3.06 \mathrm{~g} / \mathrm{cm}^{3}$, and high porosities of $29 \%$ to $41 \%$ were measured in this lithology (Fig. F15).

\section{$P$-wave velocity}

$P$-wave velocities were measured with the Geotek MSCL $P$-wave logger (PWL) on whole cores and the PWS3 contact sensor system on a modified Hamilton frame on $\sim 2-4 \mathrm{~cm}$ long 1 inch round discrete samples of semilithified and lithified sediments (see the "Methods" chapter). Velocities in one transverse (x) direction were measured on the plugs. $P$-wave velocity profiles in the last deglacial sequence and in volcaniclastic-dominated holes are highly discontinuous because of low recovery and lack of saturation. Hole M0008A contains intervals with PWL-measured sections that consist predominantly of volcaniclastic sand with low velocities of $\sim 1800 \mathrm{~m} / \mathrm{s}$, which can be expected for an unconsolidated sand (Fig. F9). The one basalt section recovered (Core 310-M0008A-8R) has high velocities of $\sim 5700 \mathrm{~m} / \mathrm{s}$, which is near the matrix velocity for the minerals making up the bulk of this rock, olivine and pyroxene, and agrees well 
with previous fresh unweathered seafloor basalts, $5940 \mathrm{~m} / \mathrm{s}$ (Hyndman and Drury, 1976).

Only the older Pleistocene sequence has generally better recovery, showing consistent velocities of $\sim 4000 \mathrm{~m} / \mathrm{s}$ (e.g., Cores 310-M0012A-13R through $19 \mathrm{R})$. Discrete velocity measurements range from 3107 to $4741 \mathrm{~m} / \mathrm{s}$ and show no clear downhole trends. No sonic logging data are available for Tiarei marginal sites.

\section{Magnetic susceptibility}

The nearby Tiarei River delivers a substantial amount of weathered volcaniclastic material to the reef system at Tiarei. Bathymetry maps reveal a complex system of river discharge over the submerged part of Tahiti Island (Hildenbrand et al., 2006). At Tiarei, this influx of volcaniclastic material produces a complex pattern of interlayered volcaniclastic sediments and carbonate reef intervals. Holes M0008A and M0022A have no reef material at all and wholly consist of volcaniclastic material (Figs. F9, F15). Magnetic susceptibility in Hole M0008A is generally high with a maximum up to $2550 \times 10^{-5}$ SI units (Fig. F9). Volcaniclastic sediments were recovered in Hole M0022A and show an overall high magnetic susceptibility response with values up to $1650 \times 10^{-5}$ SI units and generally between 200 and $400 \times 10^{-5}$ SI units (Fig. F15). Sites M0010-M0014 have generally low recovery in the last deglacial sequence but show generally high values for magnetic susceptibility, with values up to $700 \times 10^{-5}$ SI units and lower limits above $200 \times$ $10^{-5}$ SI units. The older Pleistocene sequence has overall lower magnetic susceptibility, with values $<200 \times 10^{-5}$ SI units (e.g., Cores 310-M0010A-16R through 20R), but locations with up to $500 \times 10^{-5} \mathrm{SI}$ units occur (e.g., Hole M0012A; 30 mbsf).

\section{Resistivity}

See "Resistivity" in the "Maraa western transect" chapter.

\section{Thermal conductivity}

Thermal conductivity measurements were carried out on suitable materials comprising sand, silt, and muddy sediment from Sites M0008 and M0011M0013 in the Tiarei area and Site M0005 in the Maraa area. Mean values are low and range between 0.9 and $1.3 \mathrm{~W} /(\mathrm{m} \cdot \mathrm{K})$. This range lies just below the range for silt $(1.4-2.1 \mathrm{~W} /[\mathrm{m} \cdot \mathrm{K}])$. Low values obtained from Tahiti sediments may represent the effect of the mixing of lithologies or complications from measurement of loosely consolidated sediments. Unconsolidation also causes difficulties in obtaining good thermal coupling between sediment and probe (see the "Methods" chapter).

\section{Diffuse color reflectance spectrophotometry}

Color reflectance data in the last deglacial sequence in each hole are highly discontinuous (Fig. F16) because of low recovery. Color reflectance values are low (15-41 $\mathrm{L}^{*}$ units) in all cores in Hole M0008A, which consists only of volcanic sandstone with basalt gravels (Fig. F9). Hole M0010A shows a general increase of $L^{*}$ values from top to bottom (from 18 to $38 \mathrm{~L}^{*}$ units) (Fig. F10). This trend reflects the lithological change from volcaniclastic sand-dominated lithologies in the upper part (e.g., Cores 310M0010A-1R through 3R) to coralgal frameworkdominated lithologies facies in the basal part (Section 10R-1, 0-100 cm). Low $L^{*}$ values $\left(17-24 \mathrm{~L}^{*}\right.$ units in Cores 310-M0011A-2R and 3R) in the upper part of Hole M0011A originate from basalt pebbles (Fig. F13). In the last deglacial sequence of Hole M0012A, low $\mathrm{L}^{*}$ values (26-52 L* units) in Cores 310-M0012A$2 \mathrm{R}, 7 \mathrm{R}, 12 \mathrm{R}$, and $13 \mathrm{R}$ correspond to terrigenous sand to silt, volcaniclastic sand, and basalt pebbles (Fig. F11). On the other hand, high $L^{*}$ values (63-76 $L^{*}$ units) in Cores 310-M0012A-9R and 11R correspond to the occurrence of massive Porites corals.

Color reflectance $\left(\mathrm{L}^{*}\right)$ trends in Hole M0014A show a similar pattern to that observed in Hole M0012A (Figs. F11, F14). In Hole M0014A, however, the abrupt downward shift corresponds to the disconformity between coral rudstone in the last deglacial sequence and Halimeda packstone with volcaniclastic sand in the older Pleistocene sequence (Section 310M0014A-13R-1, $50 \mathrm{~cm} ; 18.78 \mathrm{mbsf})$, where $\mathrm{L}^{*}$ values shift from 50 to $24 \mathrm{~L}^{*}$ units.

Color reflectance patterns are equal for the basal part of the last deglacial sequence and the upper part of the older Pleistocene sequence in Holes M0010A, M0011A, and M0012A (Figs. F10, F11, F13, F16), although lowest $\mathrm{L}^{*}$ values can be observed in some intervals containing basalt pebbles. In Hole M0022A, $\mathrm{L}^{*}$ values (average $=19-58$ and $31 \mathrm{~L}^{*}$ units) are low because basalt and volcaniclastic siltstone are the dominant lithofacies (Fig. F15).

\section{Hole-to-hole correlation}

Borehole locations at Tiarei marginal sites are not directly related and form a group of holes that do not directly correspond to specific assembly of target locations in the reef system. In addition, overall recovery at this site averaged $34 \%$, which makes correlation difficult. Hole-to-hole correlation is therefore not possible. 


\section{Site-to-site correlation}

The last deglacial/older Pleistocene sequence boundary, a sharp and abrupt unconformity, is the key correlation surface through all boreholes. Above this boundary, the last deglacial sequence is composed of open coralgal-microbialite framework with highly variable density, porosity, and velocity values. Correlation using these properties proves to be difficult. Magnetic susceptibility allows good correlation within sites, but it does not permit site-to-site correlation. The boundary is characterized by a sharp and abrupt increase in density and velocity and a decrease in porosity. Emergence and subaerial exposure have altered the upper few meters of this sequence, confirmed by cement crusts, infillings of karst features with younger sediments, and other diagenetic features (see "Sedimentology and biological assemblages"). The depth of the boundary is not constant. At Tiarei outer ridge sites, the boundary is present at $\sim 118$ mbsl. At Tiarei inner ridge sites, the boundary occurs at $\sim 94 \mathrm{mbsl}$. This would indicate that the last deglacial sequence was deposited on an irregular antecedent topography.

\section{Geochemistry}

Hole M0008A was drilled more proximal to the island of Tahiti than any other Expedition 310 site and recovered volcaniclastic sediments. This makes Site M0008 unique, and its interstitial water (IW) geochemistry will be discussed separately. In all of the IW profiles, a barrier to diffusion is evident at $\sim 18$ mbsf ( $80.65 \mathrm{mbsl})$, which corresponds to the position of a large basalt boulder recovered from Sections 310-M0008A-7R-CC through 8R-1. The lack of a chilled margin at the top and bottom of this basalt suggests that it is not a continuous layer of basalt providing an impervious layer. However, the seismic profile used for site selection indicates a strong continuous reflector at approximately the same depth, suggesting the basalt may represent a continuous layer. Ultimately, with no recovery of Section 310M0008A-7R-1 above the basalt, the nature of the diffusion barrier remains uncertain.

All geochemical pore water data are presented in tables allsitesIW.xls and IWsaturation.xls in "Supplementary Material."

\section{pH, alkalinity, ammonia, chloride, and sulfate}

Above 18 mbsf (80.65 mbsl) in Subunit A (see "Sedimentology and biological assemblages"), the $\mathrm{pH}$ of IW samples is like ambient seawater, but below that depth, $\mathrm{pH}$ decreases sharply downhole un- til pore waters are slightly acidic (Fig. F17A). The IW alkalinity profile essentially traces that of $\mathrm{pH}$ (Fig. F17B). This increase in free $\mathrm{H}^{+}$results in an undersaturation of aragonite and calcite as calculated using PHREEQC software (free from USGS; wwwbrr.cr.usgs.gov/projects/GWC_coupled/phreeqc/) and shown in Figure F17N. Just below 18 mbsf, significant amounts of ammonia are also detected (Fig. F17C), indicating microbial activity. Ammonia appears to diffuse downward from this source just below the diffusion barrier at $\sim 18$ mbsf. Chloride in the pore waters is essentially like seawater with a slight depletion at the bottom of the section (Fig. F17D). This precludes the influence of significant amounts of freshwater in these sediments. Sulfate concentrations do not significantly deviate from seawater values at any depth.

\section{$\mathrm{Mg}, \mathrm{K}, \mathrm{Ca}$, and $\mathrm{Sr}$}

$\mathrm{Mg}$ concentrations of IW samples are similar to that of seawater (Fig. F17E), whereas K concentrations become depleted with depth below the diffusion barrier at $\sim 18$ mbsf. Both $\mathrm{Ca}$ and $\mathrm{Sr}$ concentrations become highly elevated with depth below the diffusion barrier (Fig. F17G, F17H), indicating dissolution of carbonate debris and/or weathering of the silicate material. The calculated undersaturation of calcite and aragonite in these pore waters (Fig. F17N) suggests that carbonate dissolution must be contributing to these enrichments.

\section{$\mathrm{Li}, \mathrm{P}, \mathrm{Mn}, \mathrm{Fe}$, and $\mathrm{Ba}$}

$\mathrm{Li}$ is depleted from its seawater value $(\sim 174 \mu \mathrm{g} / \mathrm{L})$ at all depths in Hole M0008A (Fig. F17I), suggesting Li uptake by clays in the siliclastic sediments (e.g., Zhang et al., 1998). P displays little variability with depth (Fig. F17J). Enrichment of $\mathrm{Mn}$ in pore waters is observed in all samples from Hole M0008A, but there is an important source at 20 mbsf $(82.65$ mbsl) below the diffusion barrier (Fig. F17K). Fe is greatly elevated in IW samples from above the diffusion barrier at $\sim 18$ mbsf but is below detection in samples from below the diffusion barrier (Fig. F17L). This pattern is unexpected because conventional wisdom suggests that $\mathrm{Mn}$ oxide reduction occurs above the zone of Fe oxide reduction in marine sediments (e.g., Berner, 1980). One possible explanation for this pattern is that most Fe has already been lost from the older sediments below the diffusion barrier. However, iron oxide-rich sediments containing small root fragments indicative of a laterite soil were recovered in this interval of Fe-free pore waters. It is very interesting that $\mathrm{Mn}$ can be mobile in these sediments below the diffusion barrier and $\mathrm{Fe}$ is not. $\mathrm{Ba}$ is highly enriched in the pore waters below the diffu- 
sion barrier at $\sim 18$ mbsf (Fig. F17M), leading to a calculated oversaturation with respect to of barite (Fig. F17N).

\section{X-ray fluorescence}

Five samples of volcanic sand/silt intervals and nine individual basalt samples were selected for bulk-rock analysis by energy dispersive polarization X-ray fluorescence analyzer (EDP-XRF) (see "Volcaniclastic sediments" in the "Overview of sites" chapter). All analyzed samples were taken from Hole M0008A. Volcanic sand/silt samples fall into two compositional groups on the basis of their position relative to the gray to orange color transition at Section 310M0008A-8R-1, $100 \mathrm{~cm}$. The two "upper" samples (Samples 310-M0008A-4R-1, 22-28 cm, and 5R-1,15$20 \mathrm{~cm}$ ) are from a continuous interval composed of gray sand and silt, whereas the three "lower" samples were taken in two orange-brown sand/silt/clay horizons (intervals 310-M0008A-14R-1, 24-28 cm, and 16R-1, 55-60 cm, from the same horizon, and interval 16R-1, 115-120 cm, from another). Wholerock samples were taken from the boulder (intervals 310-M0008A-7R-CC, 4-13 cm, and 8R-1, 42-51 cm) and cobble (interval 8R-1, 61-80 cm) in the rubble unit above the gray to orange color transition and from pebbles (intervals 9R-CC, $0-5 \mathrm{~cm}, 10 \mathrm{R}-1,27-30$ $\mathrm{cm}, 14 \mathrm{R}-1,0-10 \mathrm{~cm}, 17 \mathrm{R}-1,0-5 \mathrm{~cm}, 17 \mathrm{R}-1,10-15$ $\mathrm{cm}$, and 17R-1, 18-23 cm) in the rubble units deeper in the hole (Subunit B; see "Sedimentology and biological assemblages").

Analytical results are shown in Table T1. Low $\mathrm{SiO}_{2}$ but fairly high $\mathrm{K}_{2} \mathrm{O}, \mathrm{P}_{2} \mathrm{O}_{5}$, and $\mathrm{TiO}_{2}$ contents $\left(\mathrm{Na}_{2} \mathrm{O}\right.$ was not analyzed) suggest that the volcanic rock samples belong to the alkalic basalt family (i.e., alkalic basalt, basanite, tephrite, and nephelinite). The two texturally similar samples that apparently come from a single boulder (interval 310-M0008A-17R-1, 10-15 cm) show many compositional similarities, but they also have differences, especially with respect to $\mathrm{MgO}$ contents. The differences may be due to flow differentiation, which is known to create compositional variation within a lava flow, or to instrumental error. Two samples (Samples 310M0008A-8R-1, 61-80 cm and 10R-1, 27-30 cm) are fairly primitive ( $>14.0 \mathrm{wt} \% \mathrm{MgO}$ and $>350 \mathrm{ppm} \mathrm{Ni}$ ), but one of them (Sample 8R-1, 61-80 cm) is highly olivine-pyroxene phyric, and therefore its composition may have been changed by crystal accumulation of olivine and pyroxene. Despite their small number, rock samples apparently show downhole compositional variation (Fig. F18A-F18C). Samples from the upper part of the hole have slightly higher incompatible element content (e.g., $\mathrm{K}$ and $\mathrm{Rb}$ ) but lower $\mathrm{SiO}_{2}$ than those from the lower part of the hole. This indicates that the shallow basalt samples are compositionally more alkalic than the deeper samples.

Volcaniclastic sand/silt samples are compositionally different from the whole-rock basalt samples in that they have lower $\mathrm{SiO}_{2}$ contents that translate to lower total weight percent of all major oxides, which is obviously due to higher volatile contents, mainly seawater, as evidenced by their high $\mathrm{Cl}$ contents. Sulfur is also high in the sand/silt samples, particularly in the upper samples. The only rock sample that is high in both $\mathrm{S}$ and $\mathrm{Cl}$ contents is a scoriaceous pebble (Sample 310-M0008A-9R-CC, 0-5 cm) that probably contains a lot of pore water. Nevertheless, the upper sand/silt samples show many compositional similarities with the basalts but the lower samples do not. The upper and lower sand/silt samples show apparent compositional differences (Fig. F19A-F19C). Because downhole compositional variations are observed in pore water chemistry, compositional differences between the upper and lower sand and silt horizons above and below the gray-orange color transition are probably real. Unlike the downhole compositional variation of the basalts, the sand/silt compositional differences are most probably related to changes in depositional settings.

Both Tahiti-Nui and Tahiti-Iti are predominantly composed of lava flows of moderately alkalic to strongly alkalic basalts; plutonic rocks are subordinate in amount and only exposed near their eroded centers (e.g., McBirney and Aoki, 1968; Cheng et al., 1993; Duncan et al., 1994). Differentiated rocks were erupted mostly in the waning stages of volcanic activity. Thus, the lithological makeup of the volcaniclastic sediments drilled during Expedition 310, particularly the preponderance of lithic basalt clasts, is a direct reflection of the geology of the island. Compositionally, the rock samples and the two upper sand/ silt samples analyzed plot with the rest of the igneous samples from Tahiti (Fig. F20A-F20C). The two primitive basalts plot with the relatively fewer high$\mathrm{MgO}$ basalts from Tahiti, whereas the other basalt samples plot with the more abundant, lower $\mathrm{MgO}$ basalts. Many of the lower MgO basalts in Tahiti can be modeled as crystal fractionation daughters of the higher MgO parents (e.g., Cheng et al., 1993; Duncan et al., 1994). The two upper volcaniclastic sand/ silt samples plot between the two basalt groups, either because their lithic basalt components are less fractionated than the lower $\mathrm{MgO}$ basalts or because they are similar to the latter but contain additional pyroxene mineral components. The three lower sand/silt samples generally plot outside the Tahiti lava field, suggesting that their compositions have been modified or altered. 
Several detailed geochemical and geochronological investigations have shown temporal evolution in the geochemistry of Tahiti lavas. For example, three volcanic series have been identified in Tahiti-Nui (Duncan et al., 1987). The oldest, or Series A, lavas were erupted before $1.3 \mathrm{Ma}$ and include rocks that now crop out in the center of the volcano. These are predominantly moderately alkalic to transitional basalts that are parental to the few observed tholeiitic basaltic andesites on the island (McBirney and Aoki, 1968). Series B lavas represent the main exposed shield phase of volcanism and were erupted between 1.3 and $0.6 \mathrm{Ma}$. They consist mainly of moderately alkalic basalts and some of their differentiates. Series $\mathrm{C}$ lavas, the youngest, represent a late-stage valleyfilling eruption phase that occurred between 0.6 and $0.3 \mathrm{Ma}$. They consist of highly alkalic lava series such as basanite and tephrite and their differentiates. With decreasing age, therefore, there is an increase in the alkalinity and fractionation of the volcanic lavas erupted in Tahiti-Nui. This is most probably the cause of the increasing alkalic character of the lithic basalt components with decreasing depth (Fig. F17A-F17C). In other words, the older (deeper) basaltic clasts mainly came from the younger, more alkalic Series B or C lavas capping most of the island, whereas the younger (shallower) clasts originated from the older, less alkalic Series A or B lavas. This hypothesis can be tested with detailed petrographic and chemical analyses of these samples and basalt clasts from other sites. Alternatively, the downhole variation is incidental and may be due to a change in the provenance of the basalt clasts.

As mentioned earlier, the downhole compositional change of the volcaniclastic sand and silt is most probably real because pore water chemistries show downhole compositional variation. More importantly, this change is consistent with the visually observed color change from gray to orange and an increase in the amounts of iron oxides/oxyhydroxides and clay (mud) with depth.

\section{References}

Berner, R.A., 1980. Early Diagenesis: A Theoretical Approach: Princeton, NJ (Princeton Univ. Press).

Cheng, Q.C., MacDougall, J.D., and Lugmair, G.W., 1993. Geochemical studies of Tahiti, Teahitia and Mehetia, Society Island chain. J. Volcanol. Geotherm. Res., 55(12):155-184. doi:10.1016/0377-0273(93)90096-A

Duncan, R.A., Fisk, M.R., and Natland, J., 1987. The development of volcanism at Tahiti, French Polynesia. Eos, Trans. Am. Geophys. Union, 68(44):1521. (Abstract)

Duncan, R.A., Fisk, M.R., White, W.M., and Neilsen, R.L., 1994. Tahiti: geochemical evolution of a French Polynesian volcano. J. Geophys. Res., 99(B12):24341-24358. doi:10.1029/94JB00991

Hildenbrand, A., Gillot, P.-Y., and Bonneville, A., 2006. Offshore evidence for a huge landslide of the northern flank of Tahiti-Nui (French Polynesia). Geochem., Geophys., Geosyst., 7:Q03006. doi:10.1029/2005GC001003.

Hyndman, R.D., and Drury, M.J., 1976. The physical properties of oceanic basement rocks from deep drilling on the Mid-Atlantic Ridge. J. Geophys. Res., 81:4042-4052.

McBirney, A.R., and Aoki, K., 1968. Petrology of the island of Tahiti. Mem.-Geol. Soc. Am., 116:523-556.

Zhang, L., Chan, L.-H., and Gieskes, J.M., 1998. Lithium isotope geochemistry of pore waters from Ocean Drilling Program Sites 918 and 919, Irminger Basin. Geochim. Cosmochim. Acta, 62(14):2437-2450. doi:10.1016/S0016-7037(98)00178-1

Publication: 4 March 2007

MS 310-109 
Figure F1. Uncemented to poorly consolidated volcaniclastic sediment (Subunit IA; interval 310-M0008A-8R$1,80-110 \mathrm{~cm})$.

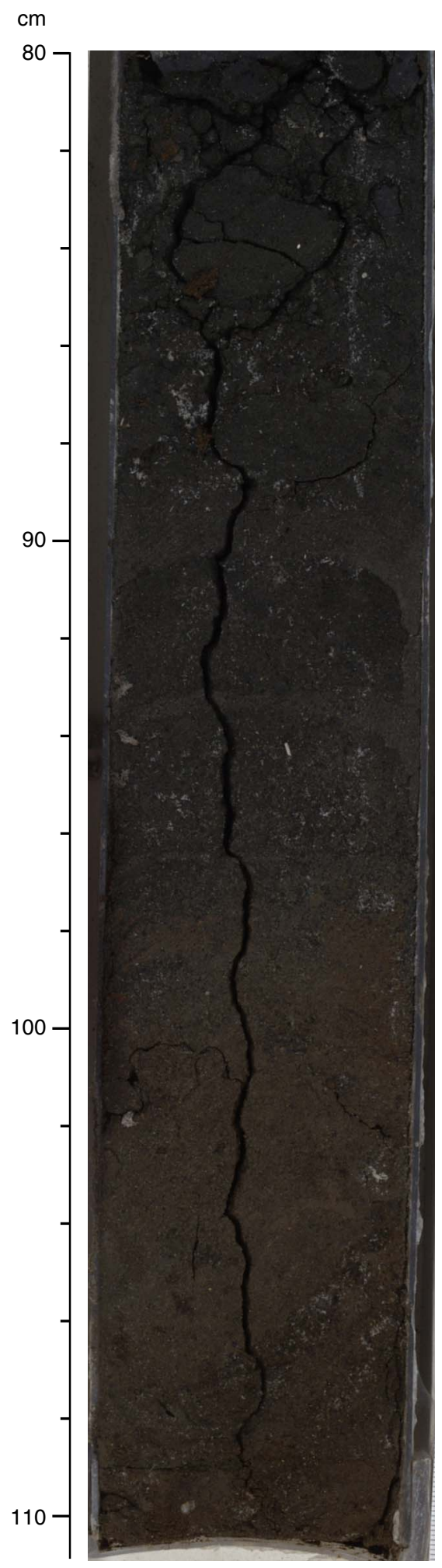


Figure F2. Volcaniclastic siltstone with subangular to subrounded pebbles of fine- to medium-grained basalt rich in olivine, pyroxene, and feldspars (Subunit IB; interval 310-M0022A-2R-1, 23-33 cm).

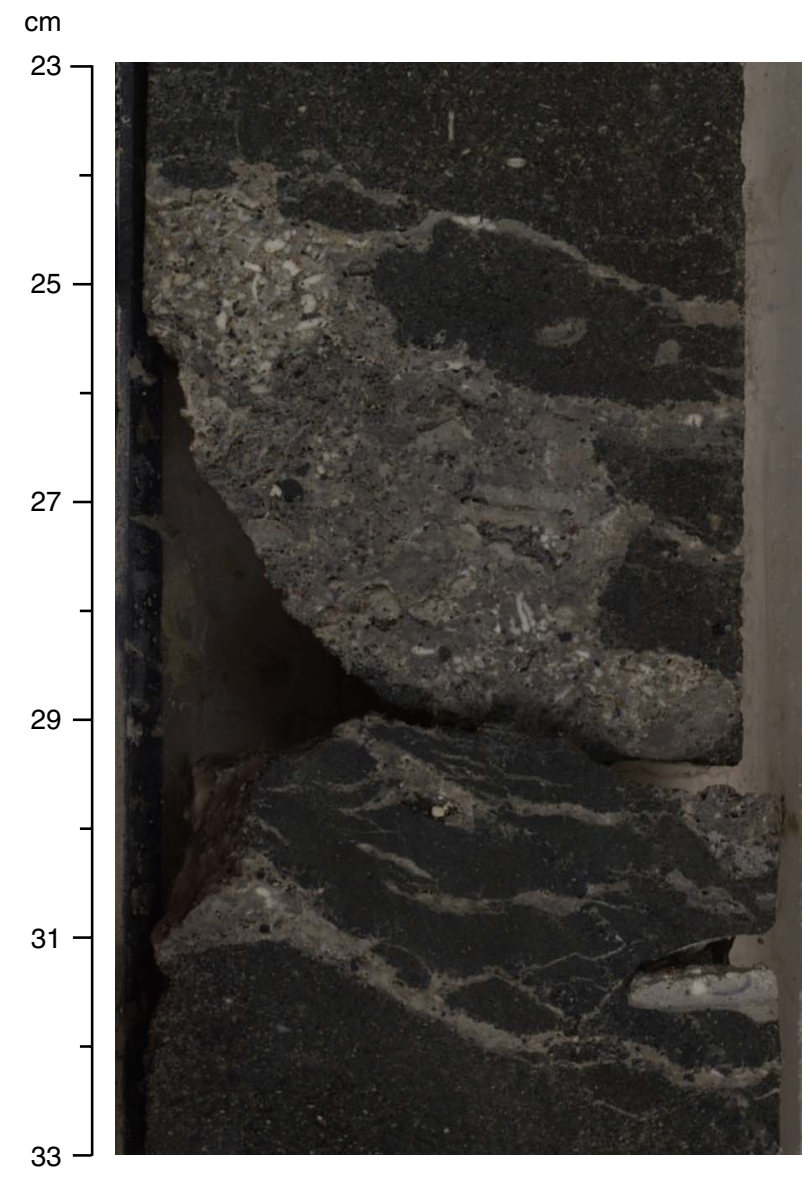


Figure F3. Robust branching colonies of Pocillopora with thick coralline algal crusts (Subunit IA; interval 310M0012A-15R-1, 18-41 cm).

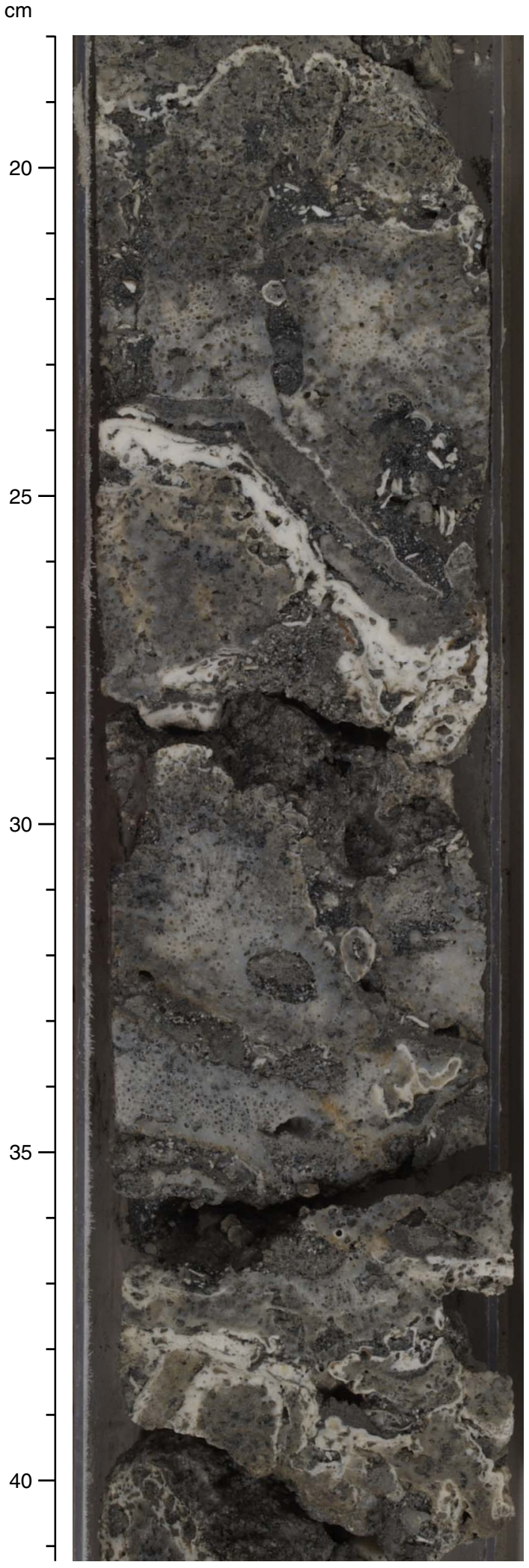


Figure F4. Framework composed of encrusting colonies of Montipora thinly encrusted with coralline algae (Subunit IC; interval 310-M0011A-7R-1, 8-21 cm).

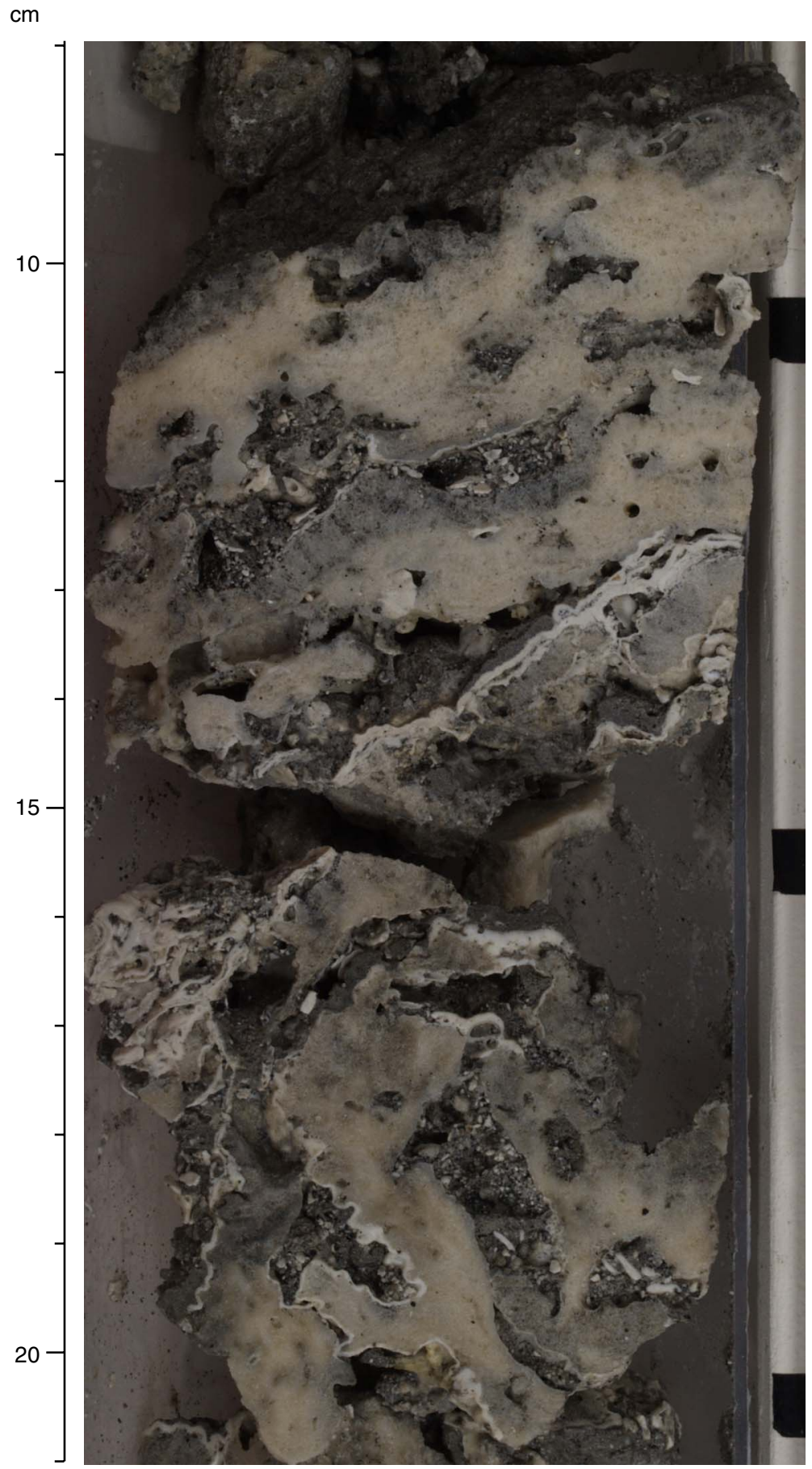


Figure F5. Boundary at $70 \mathrm{~cm}$ (below break in core) characterized by undulating hardground with dark stain below surface (Unit I/II boundary; interval 310-M0011A-9R-1, 64-74 cm).

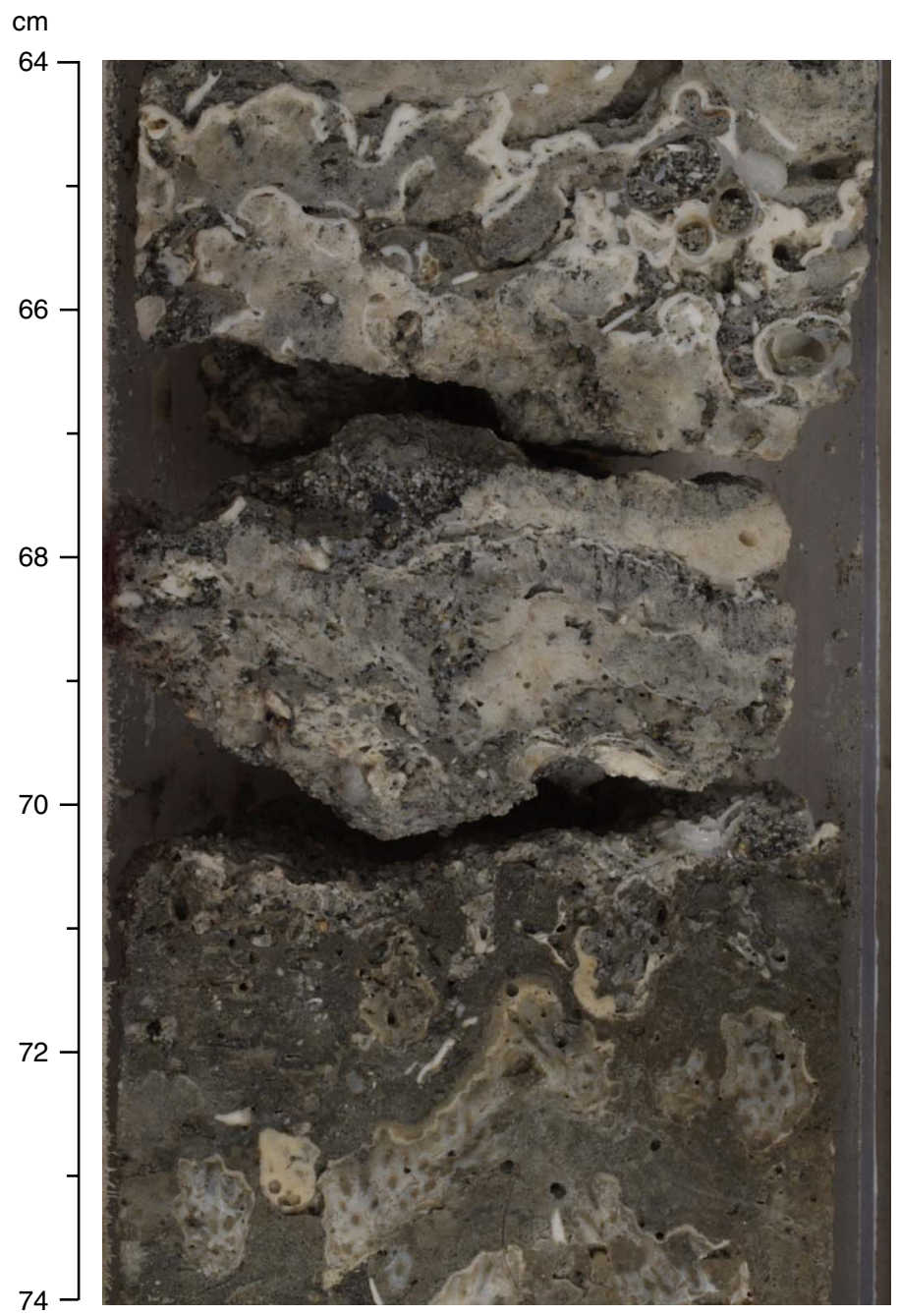


Figure F6. Sharp boundary at $30 \mathrm{~cm}$ draping over the basalt pebble (Unit I/II boundary; interval 310-M0012A$16 \mathrm{R}-1,16-40 \mathrm{~cm})$.

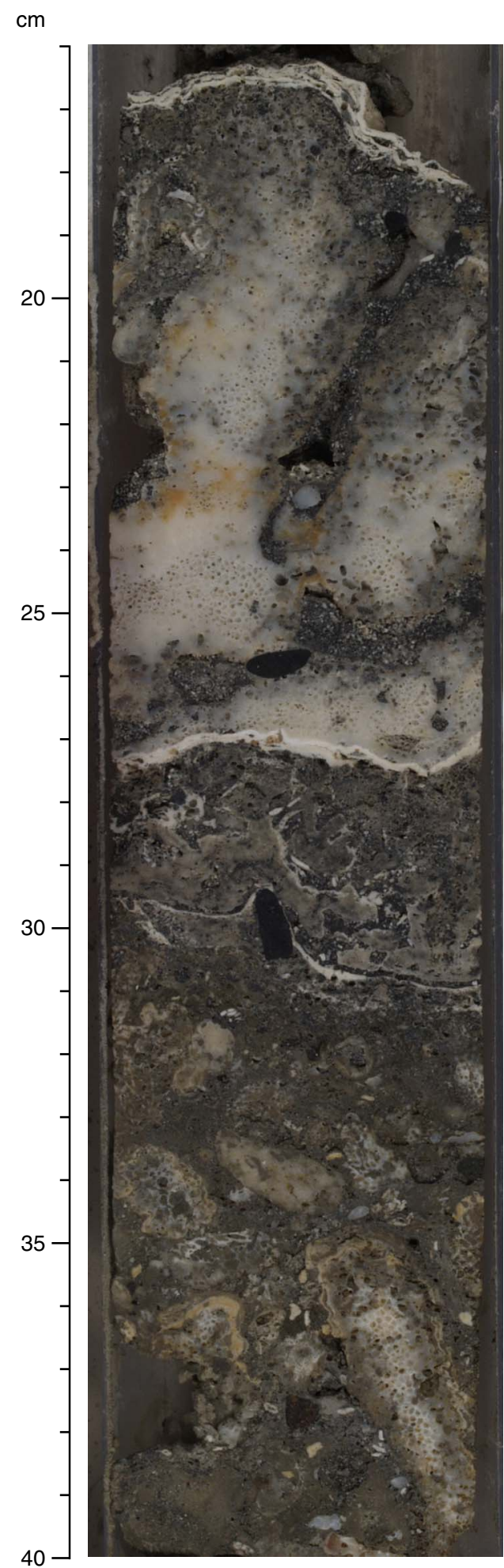


Figure F7. Grainstone rich in Halimeda segments and other skeletal components and volcaniclastic grains (Unit II base; interval 310-M0014A-13R-1, 25-57 cm).

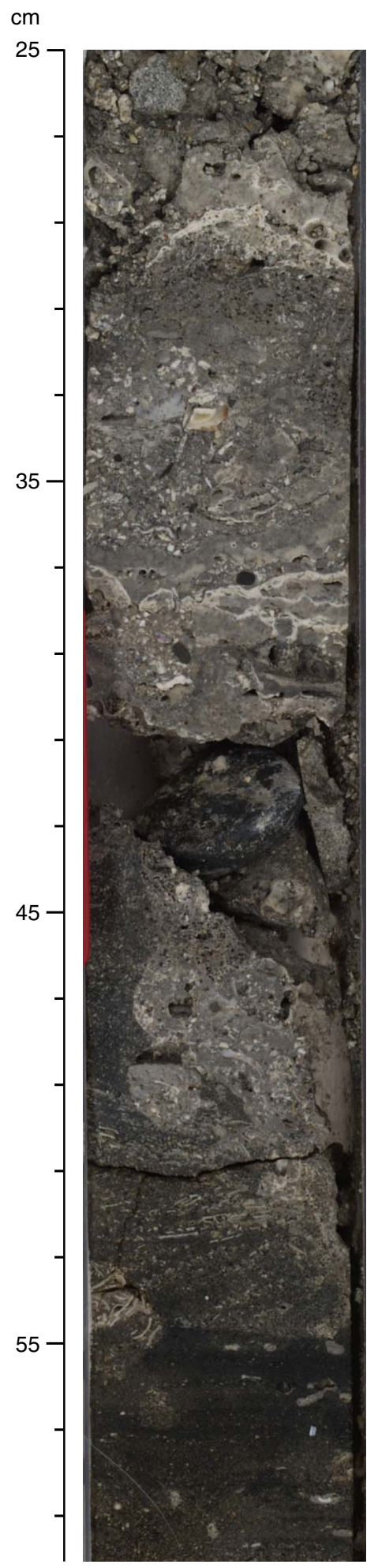


Figure F8. Sandy skeletal grainstone rich in Halimeda segments and fine to medium sand-sized volcanic grains (Unit II base; interval 310-M0014A-13R-1, 105-115 cm).

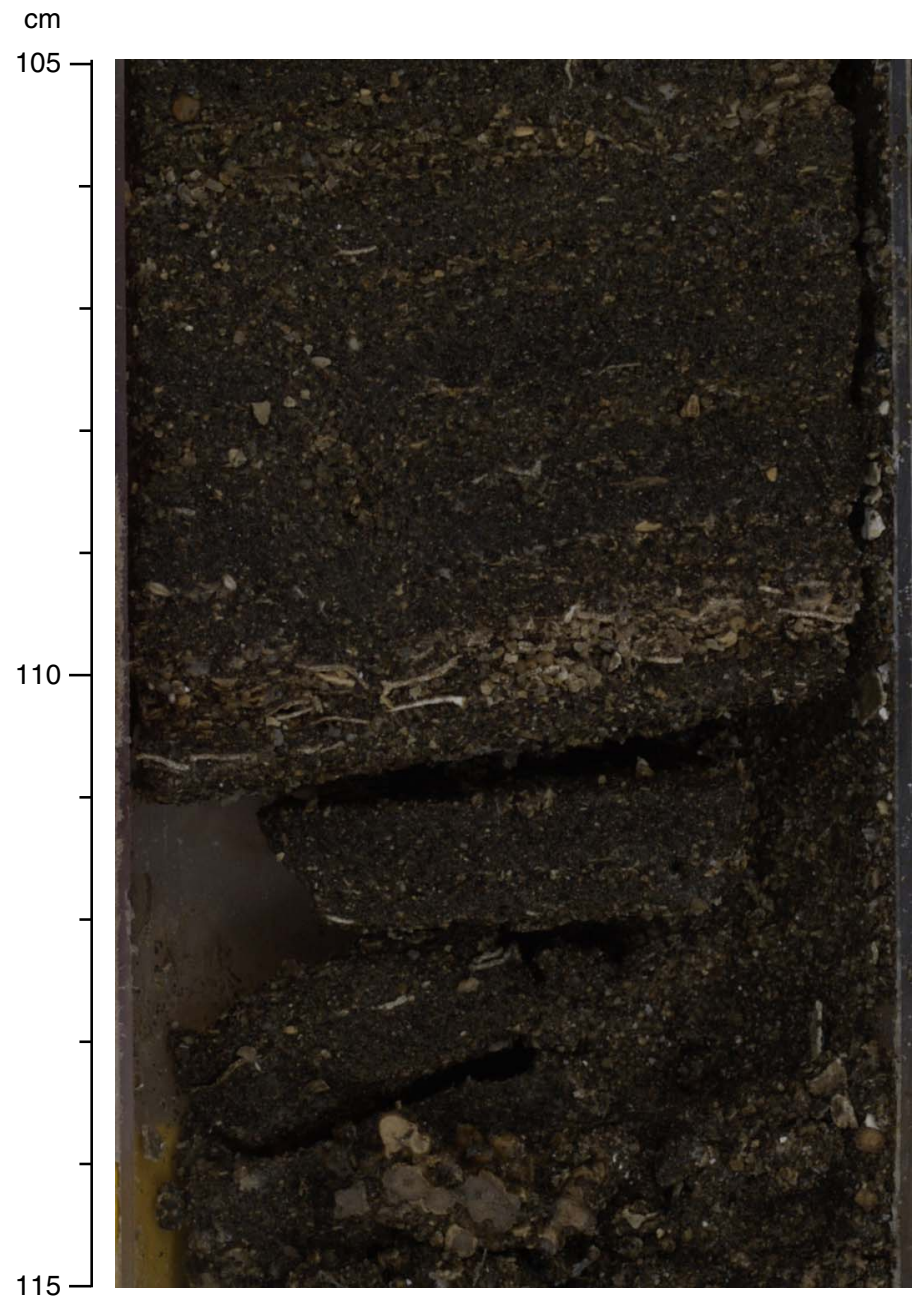


Figure F9. Velocity, bulk density, magnetic susceptibility, and porosity as a function of depth in Hole M0008A. Discrete measurements are superimposed (red circles).

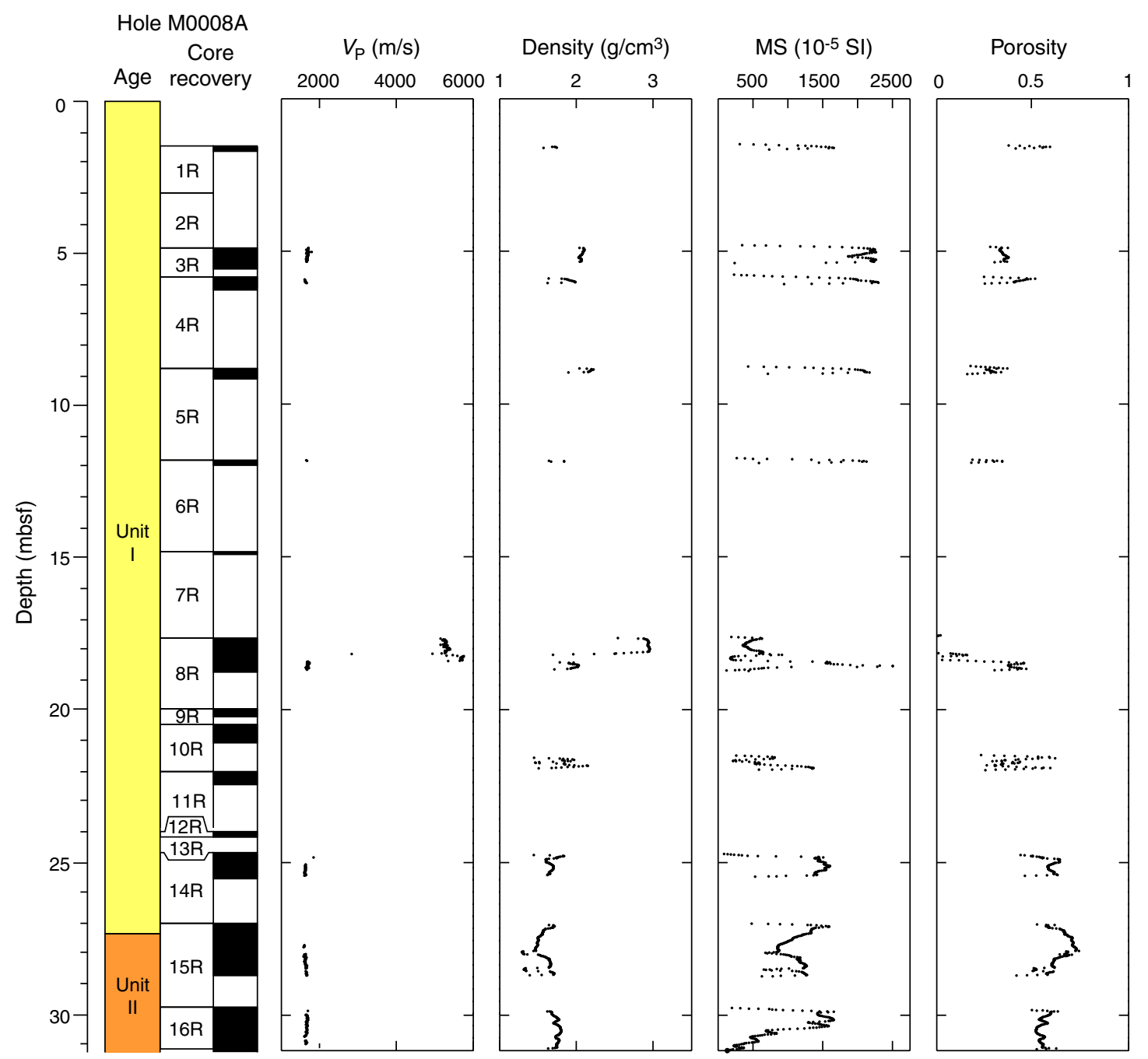


Figure F10. Velocity, bulk density, magnetic susceptibility, and porosity as a function of depth in Hole M0010A. Discrete measurements are superimposed (red circles).

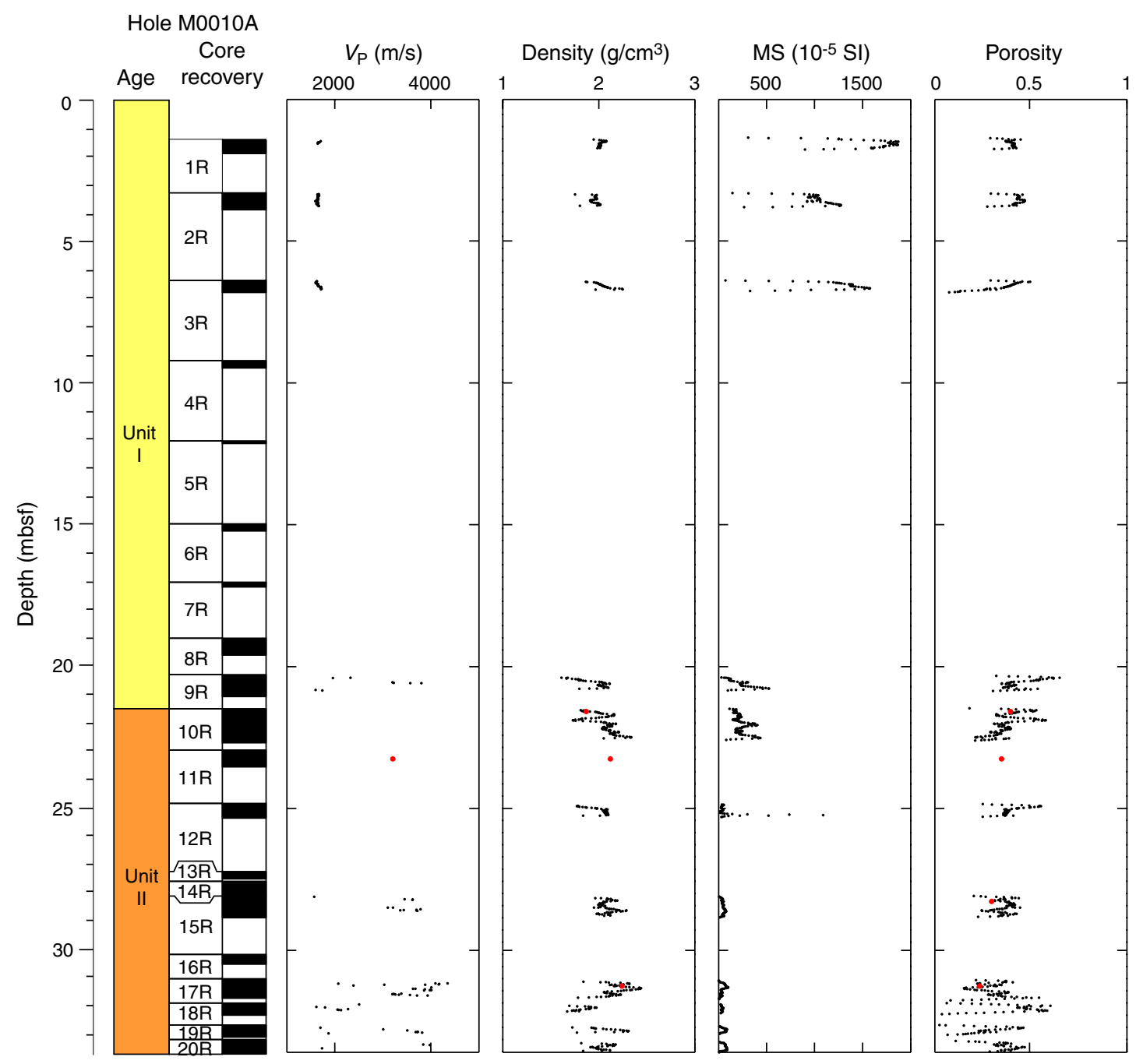


Figure F11. Velocity, bulk density, magnetic susceptibility, and porosity as a function of depth in Hole M0012A. Discrete measurements are superimposed (red circles).

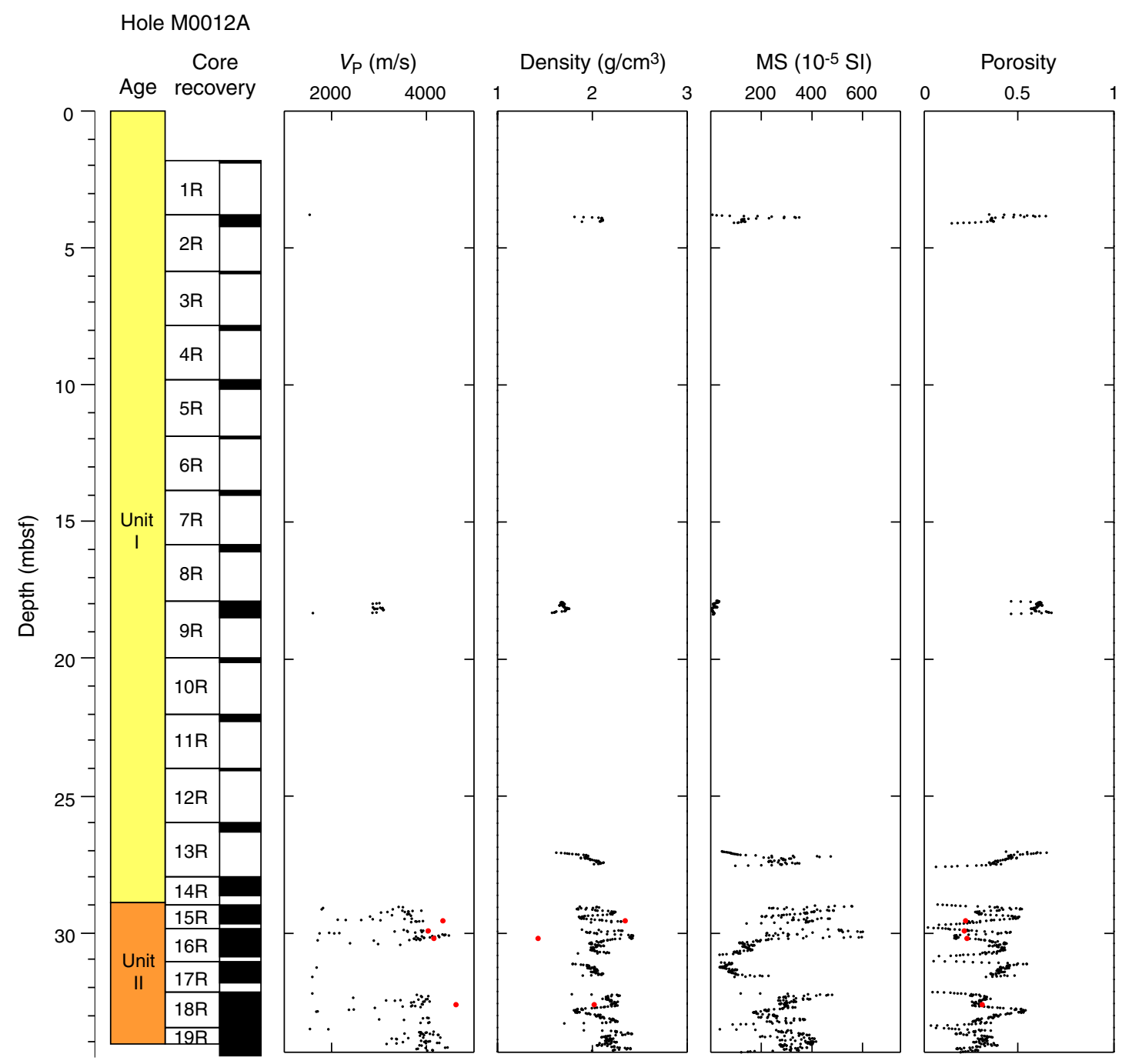


Figure F12. Velocity, bulk density, magnetic susceptibility, and porosity as a function of depth in Hole M0013A. Discrete measurements are superimposed (red circles).

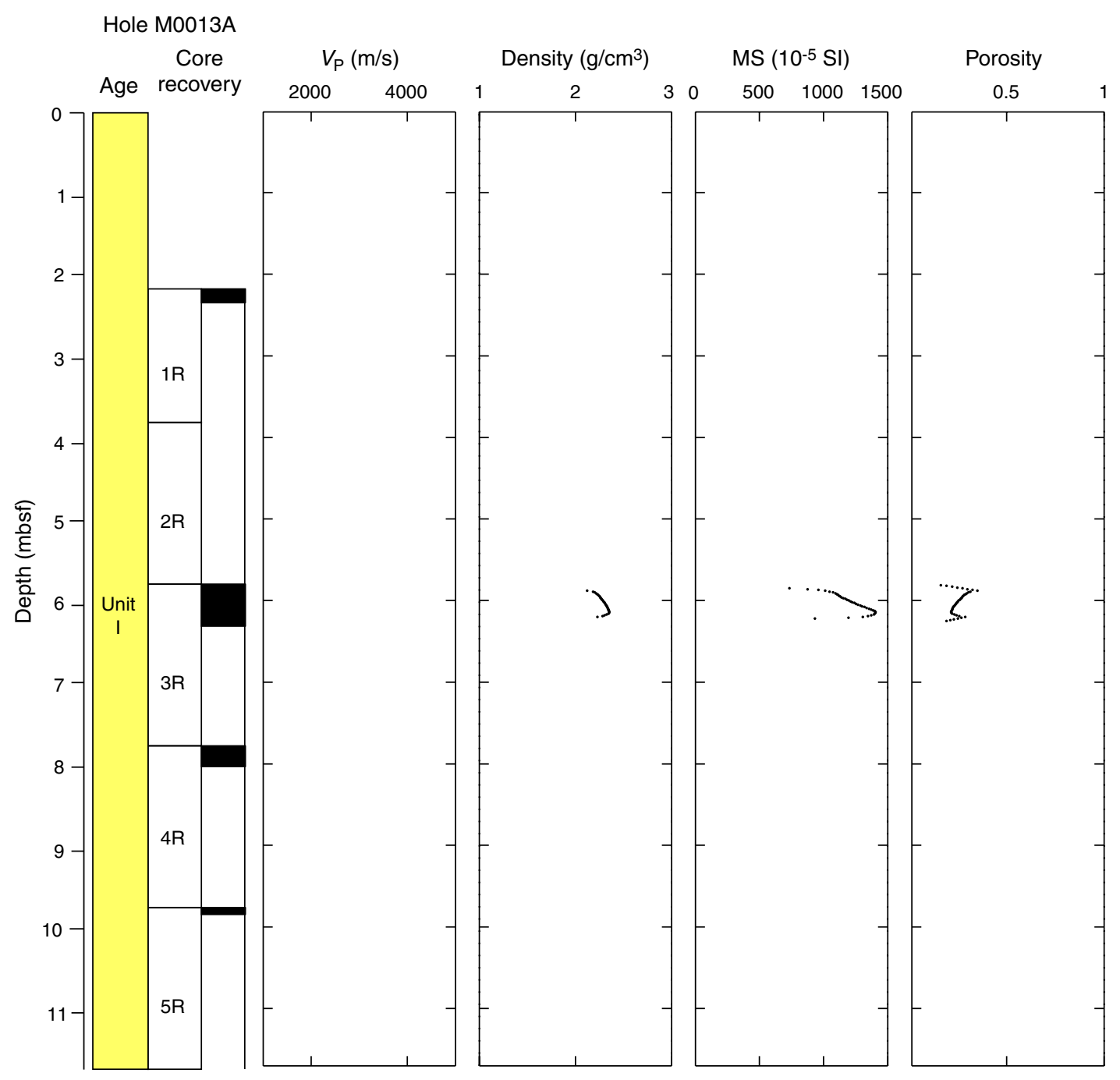


Figure F13. Velocity, bulk density, magnetic susceptibility, and porosity as a function of depth in Hole M0011A. Discrete measurements are superimposed (red circles).

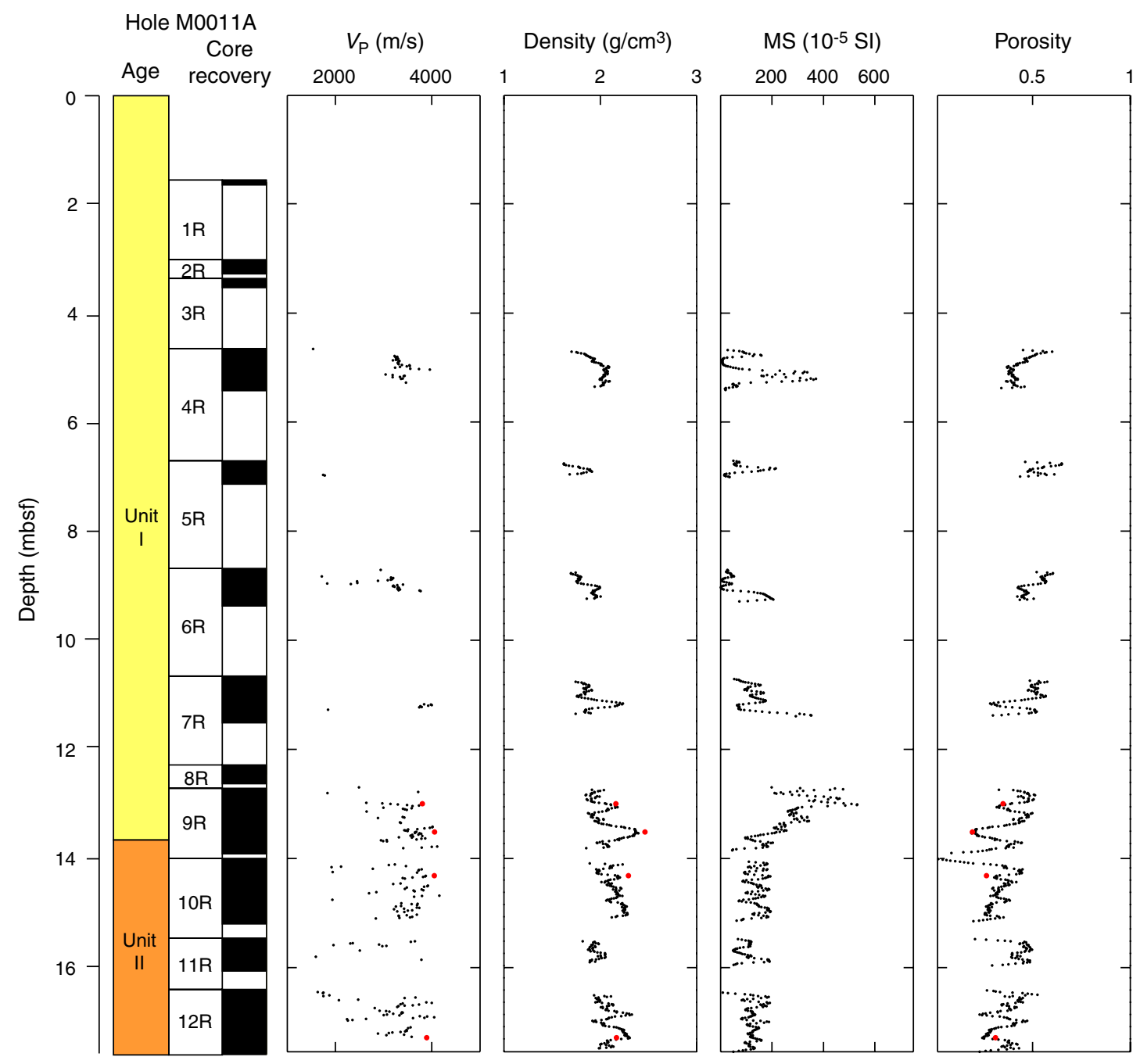


Figure F14. Velocity, bulk density, magnetic susceptibility, and porosity as a function of depth in Hole M0014A. Discrete measurements are superimposed (red circles).

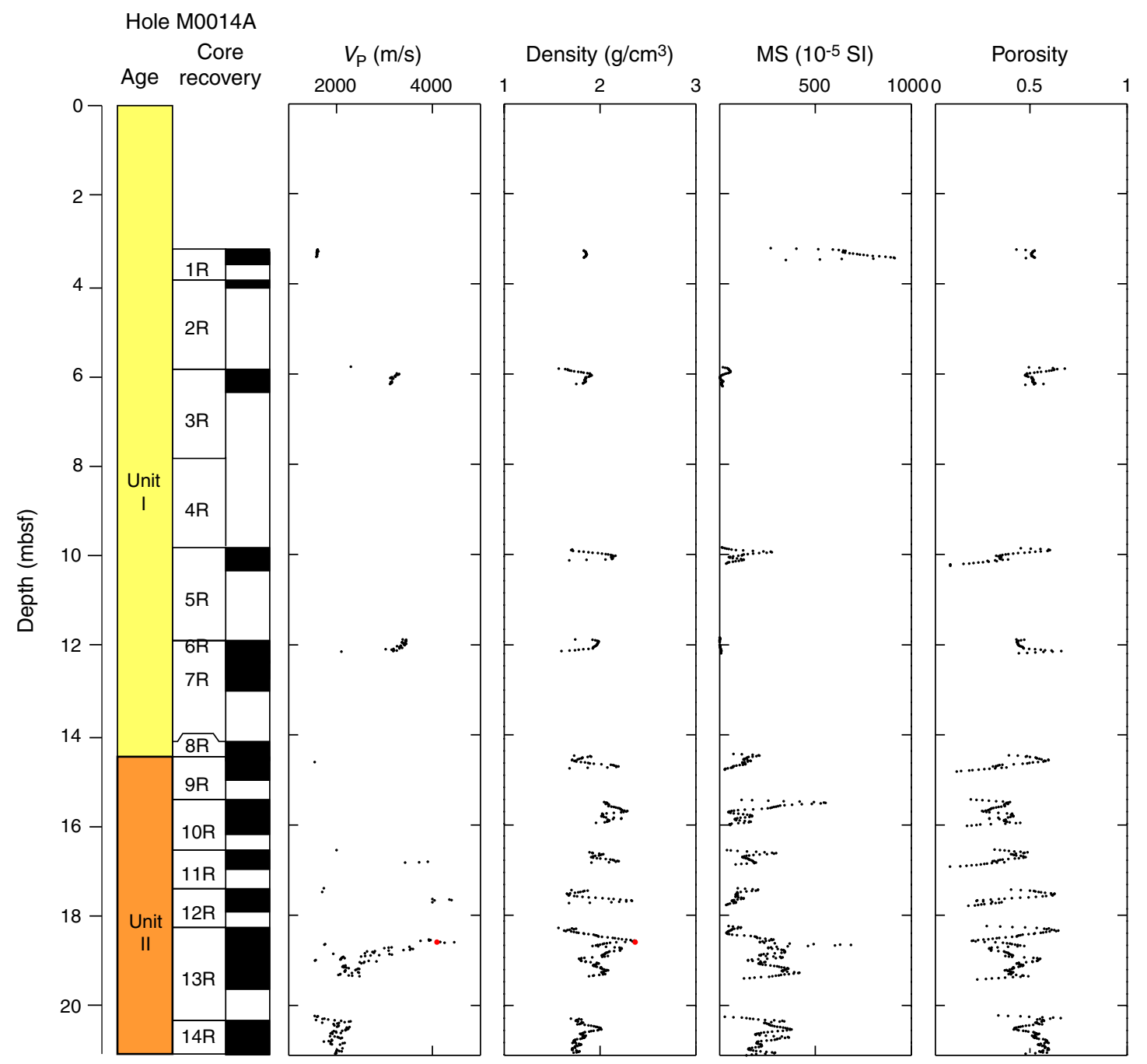


Figure F15. Velocity, bulk density, magnetic susceptibility, and porosity as a function of depth in Hole M0022A. Discrete measurements are superimposed (red circles).

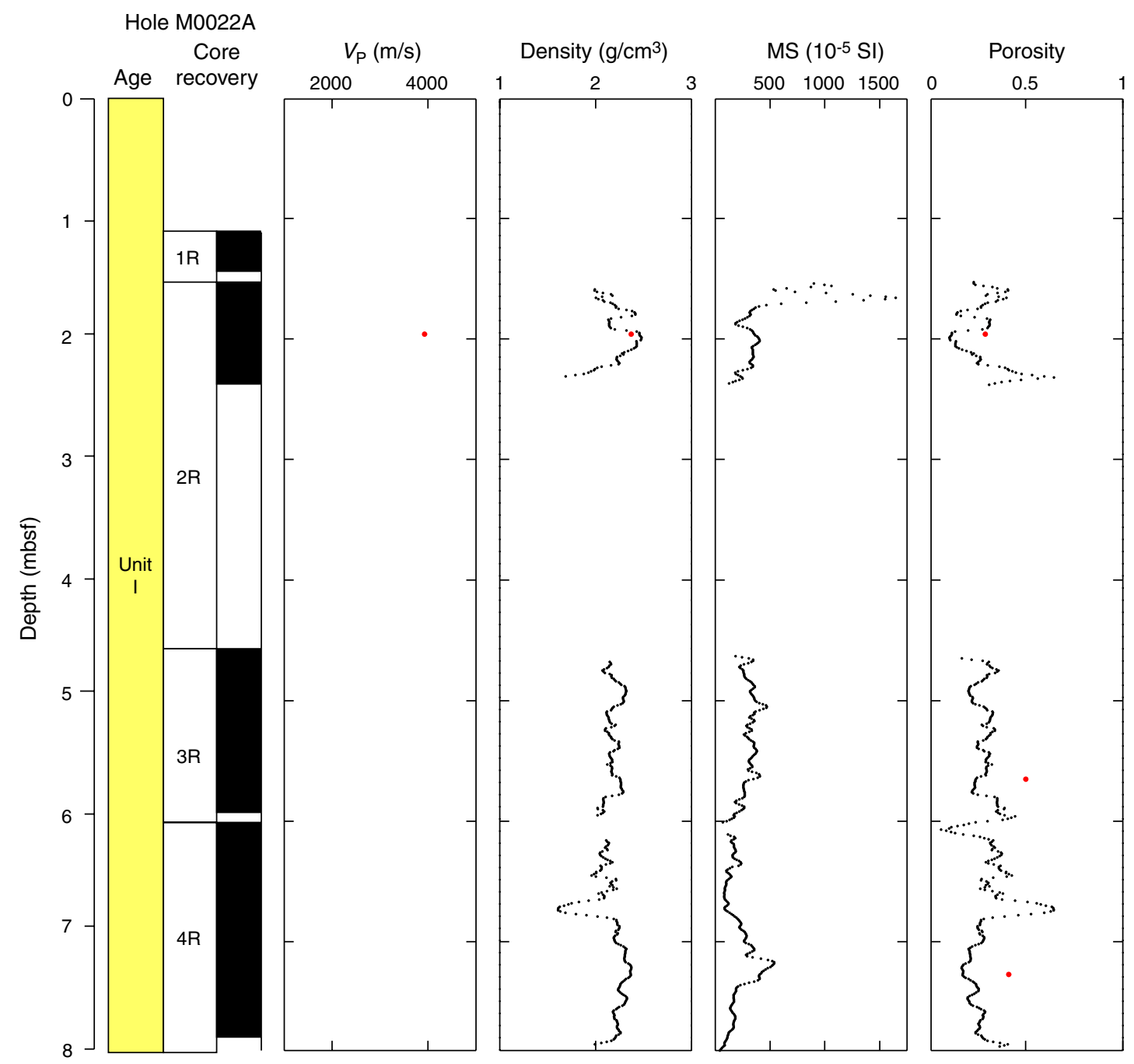


Figure F16. Color reflectance $\left(\mathrm{L}^{*}\right)$ data from Holes M0008A, M0010A, M0011A, M0012A, M0014A, and M0022A. For plotting purposes, Holes M0010A, M0011A, M0012A, M0014A, and M0022A are offset from Hole M0008A by 40, 80, 130, 190, and $270 \mathrm{~L}^{*}$ units, respectively.

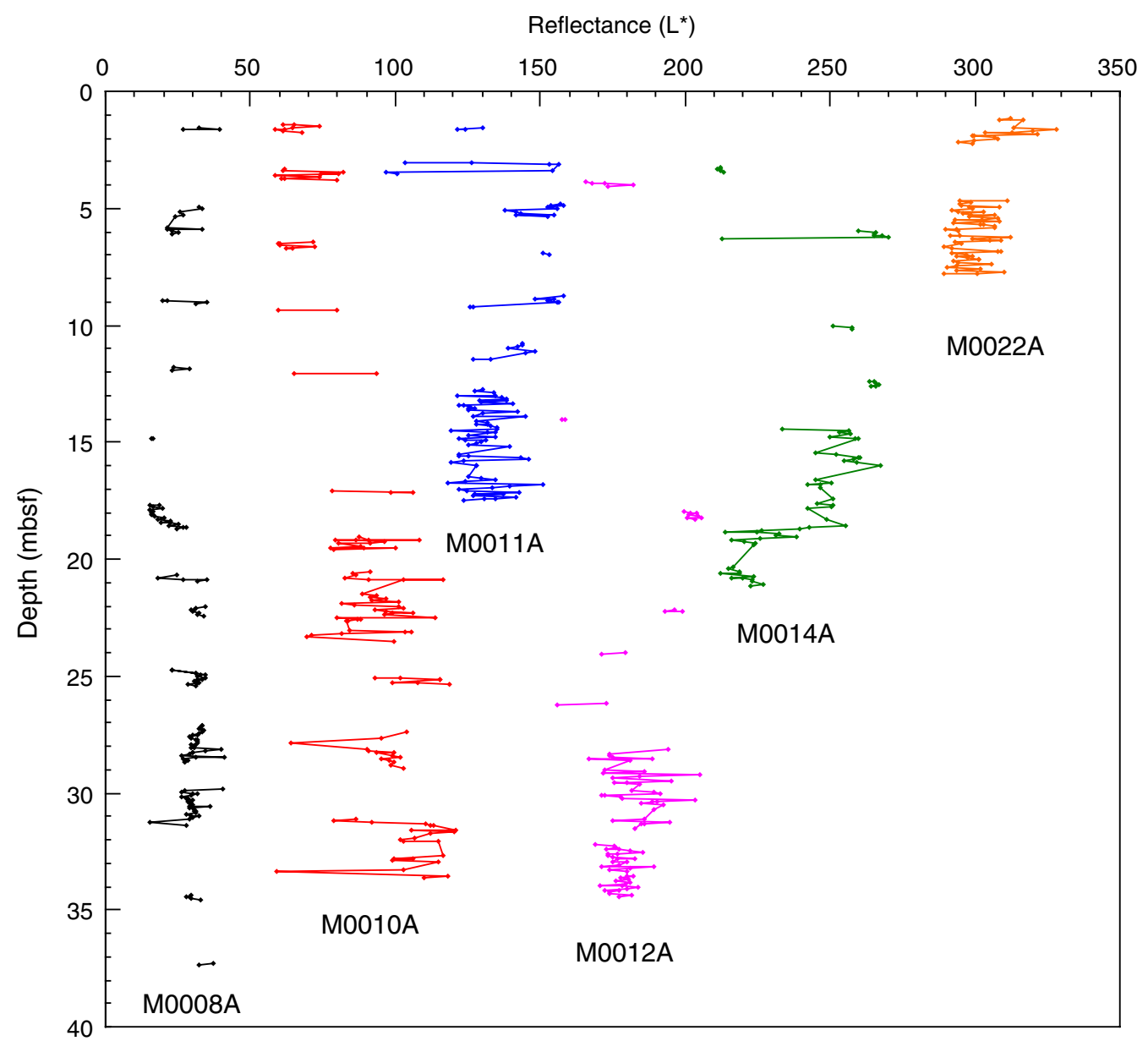


Figure F17. IW chemistry at Tiarei marginal sites. Chemical changes at $\sim 18$ mbsf reflect the presence of a barrier to diffusion, which corresponds to the depth of a large basalt boulder recovered and the presence of a strong seismic reflection. A. pH. B. Alkalinity. C. Ammonia. D. Chloride. E. Mg. F. K. G. Ca H. Sr. (Continued on next page.)
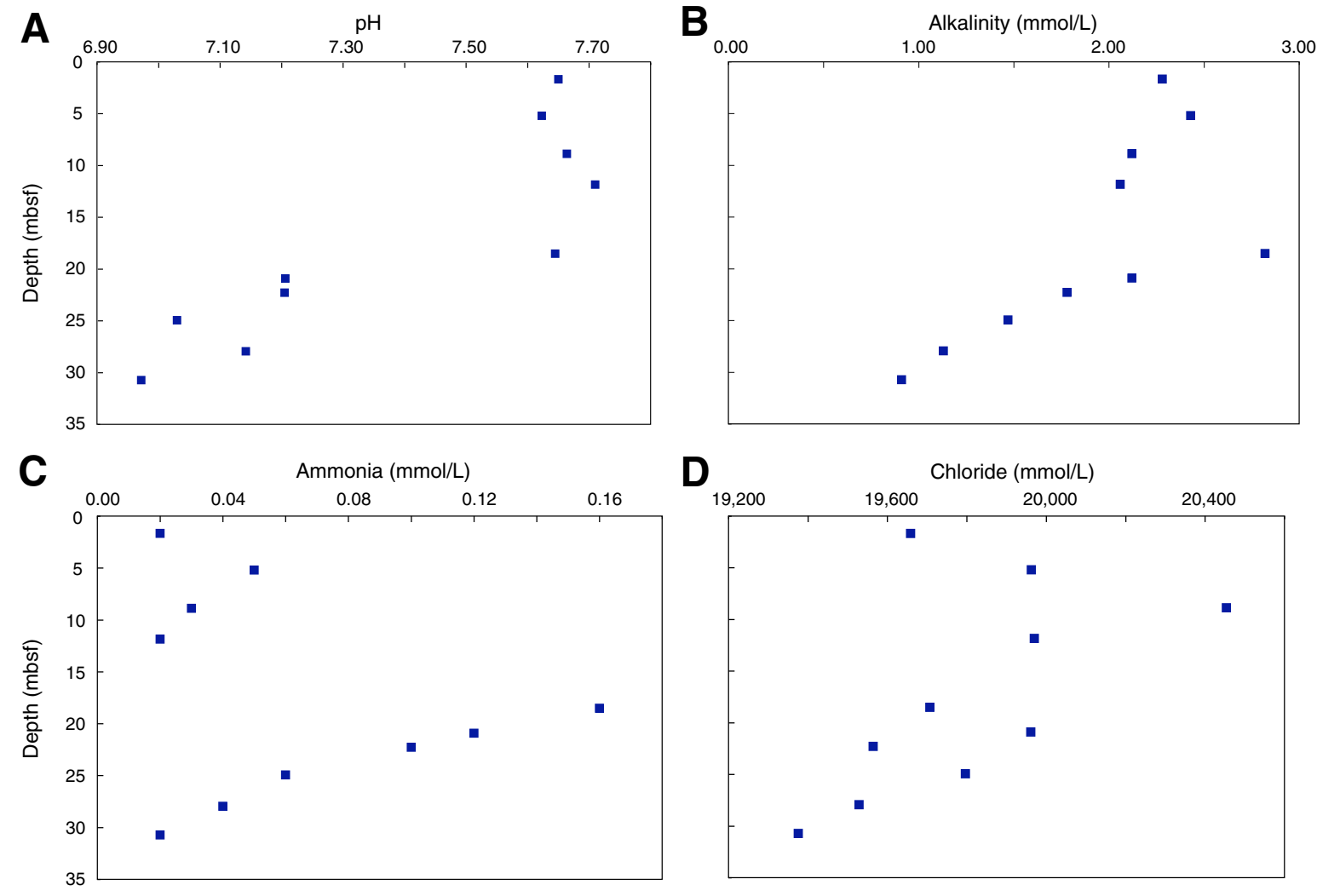

D
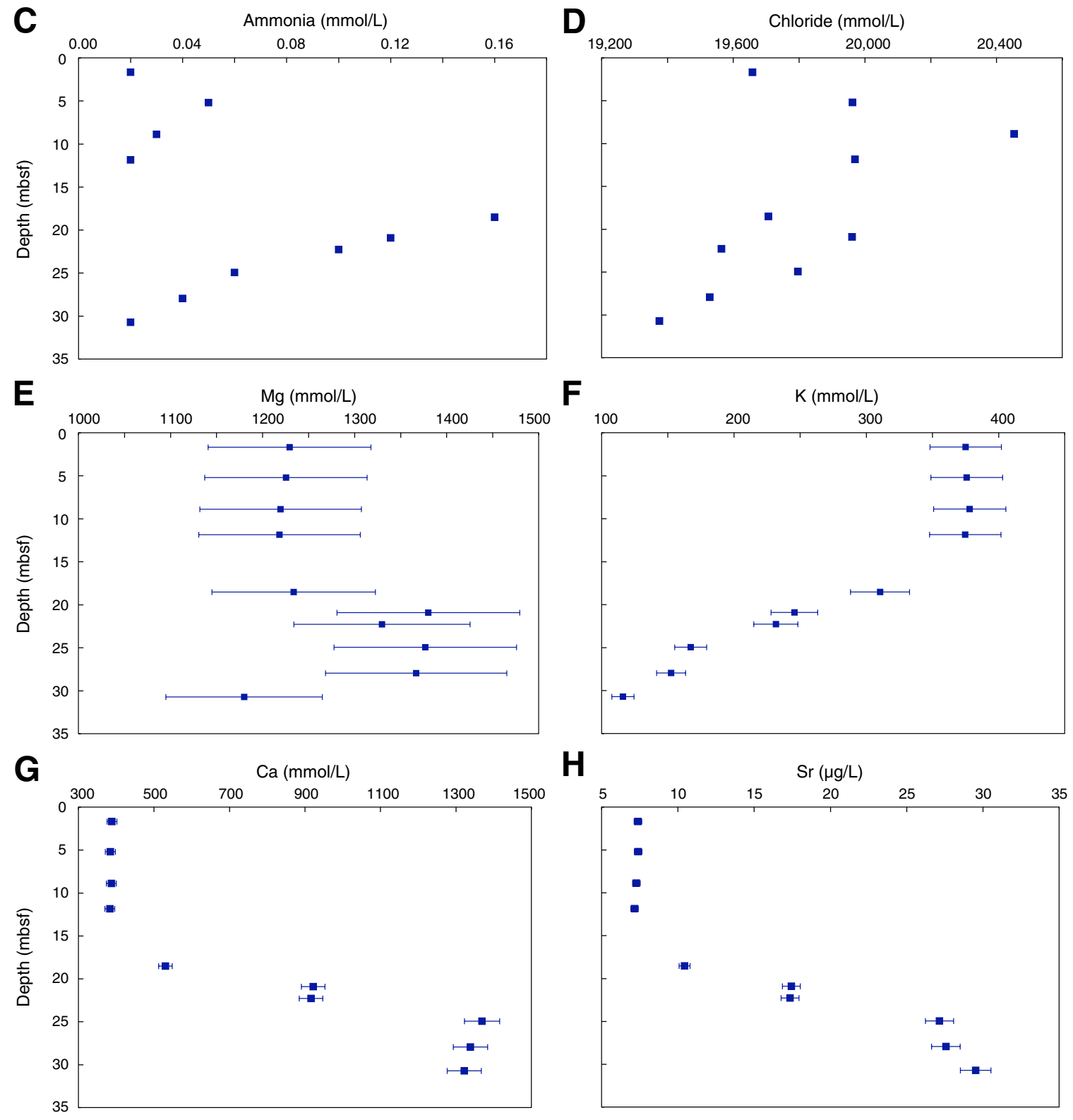

H

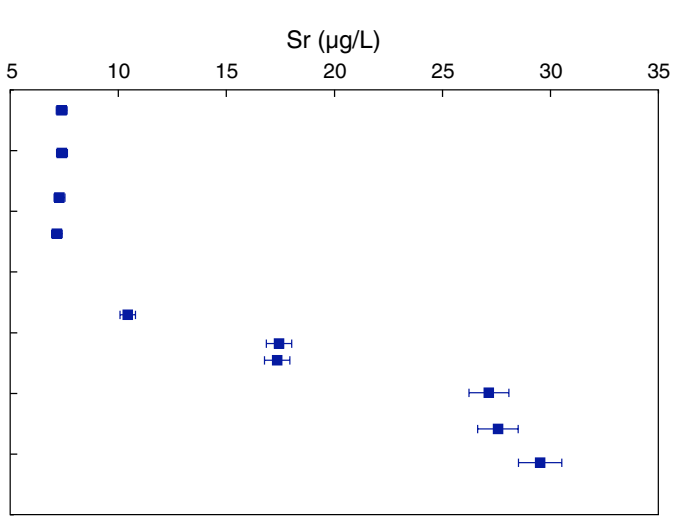


Expedition 310 Scientists

Tiarei marginal sites

Figure F17 (continued). I. Li. J. P. K. Mn. L. Fe. M. Ba. N. Carbonate mineral starvation.

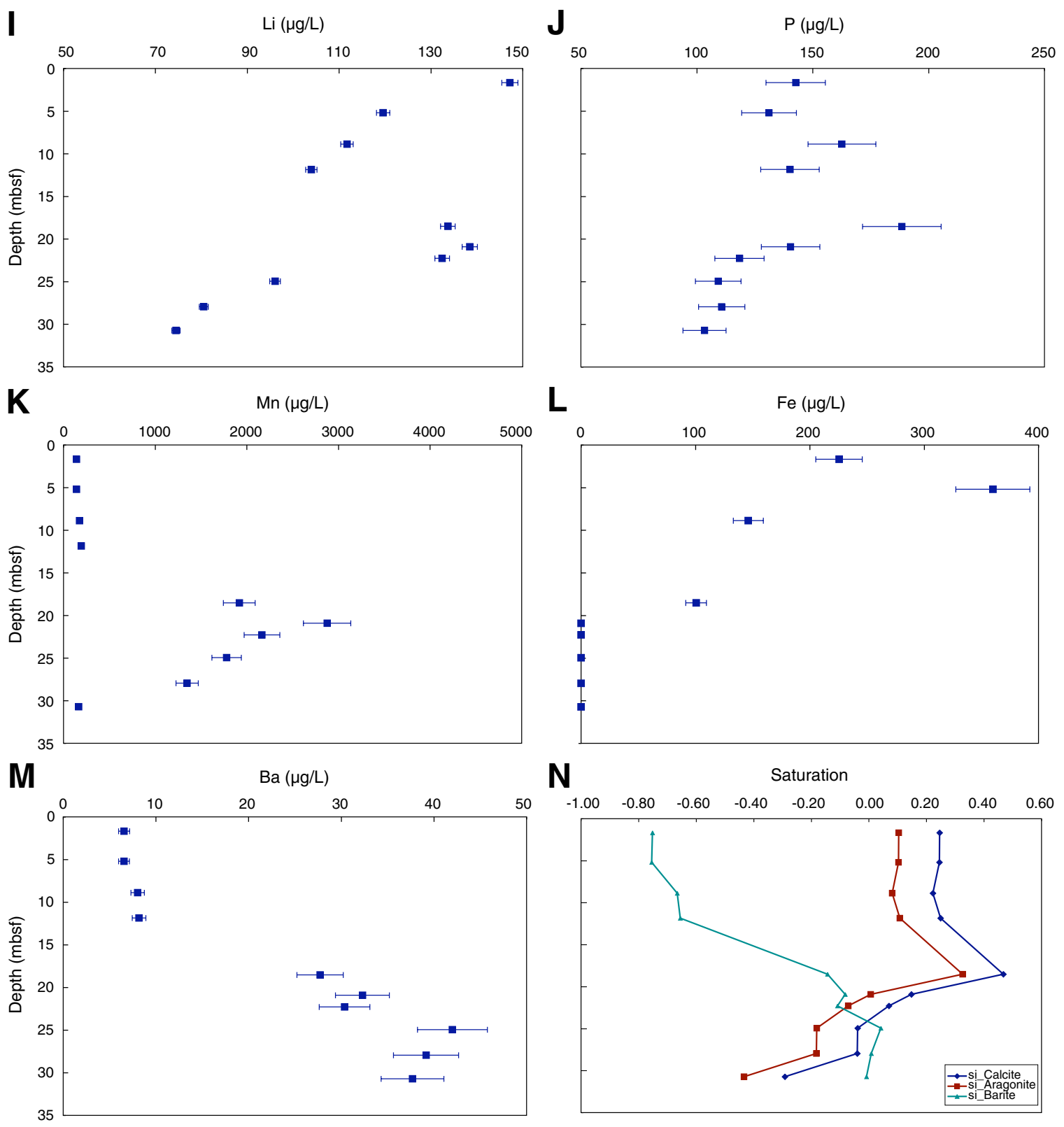

Proc. IODP | Volume 310

27 
Figure F18. X-ray fluorescence results from select volcanic rock samples from Tiarei marginal sites. Note downhole compositional variation in (A) $\mathrm{SiO}_{2}$, (B) $\mathrm{K}_{2} \mathrm{O}$, and (C) $\mathrm{Rb}$.

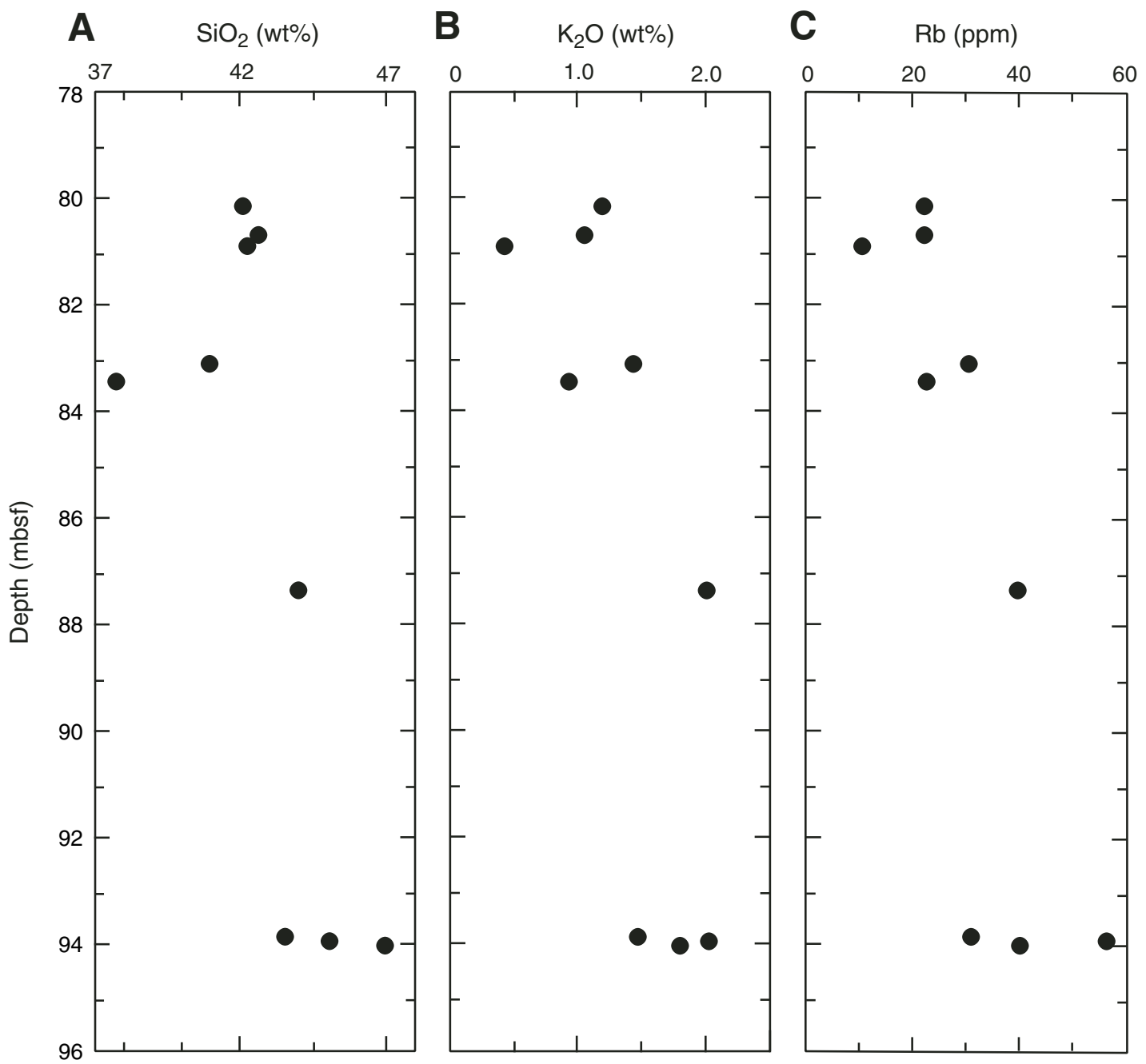


Figure F19. X-ray fluorescence results from select volcaniclastic sand/silt samples from Tiarei marginal sites. Note downhole compositional variation in (A) $\mathrm{CaO}$, (B) $\mathrm{FeO}$, and (C) $\mathrm{Rb}$.

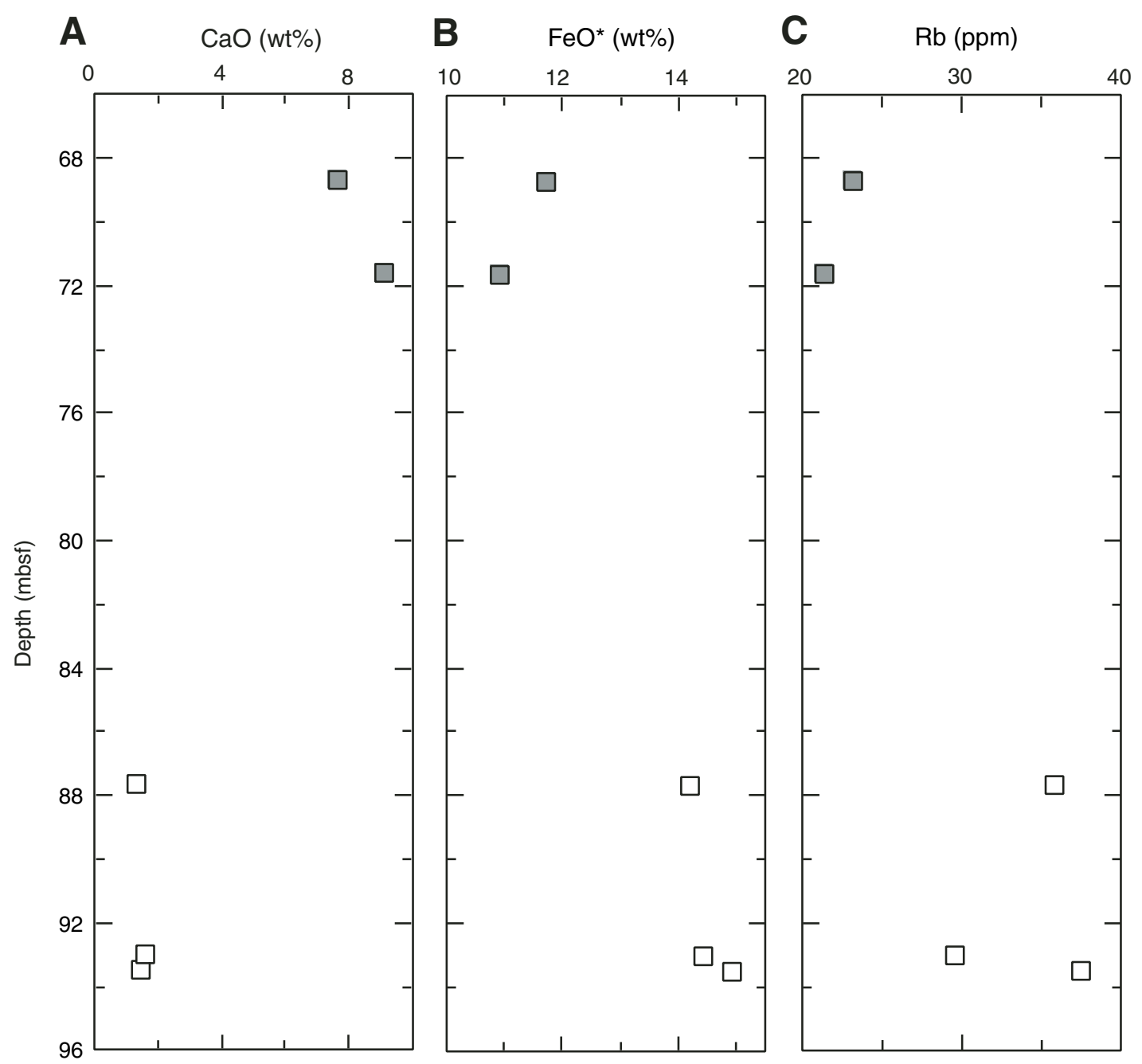


Figure F20. Analysis of igneous samples. A. $\mathrm{MgO}$ vs. FeO. B. $\mathrm{MgO}$ vs. $\mathrm{K}_{2} \mathrm{O}$. C. $\mathrm{MgO}$ vs. $\mathrm{SiO}_{2}$.
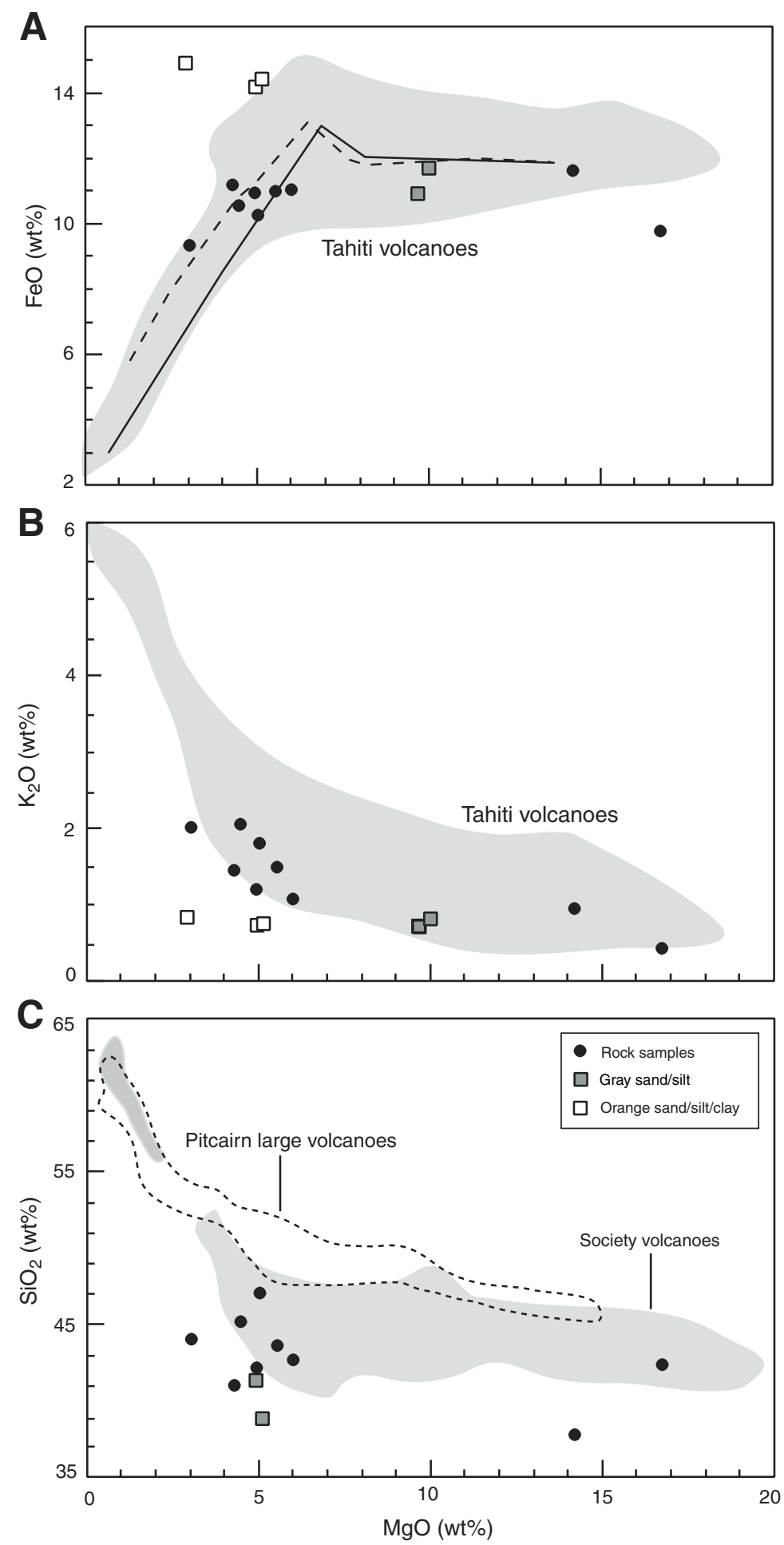
Table T1. Major and trace element analyses of representative volcaniclastic sediments, Hole M0008A.

\begin{tabular}{|c|c|c|c|c|c|c|c|c|c|c|c|c|c|c|}
\hline \multirow[b]{2}{*}{$\begin{array}{l}\text { Core, section, } \\
\text { interval }(\mathrm{cm})\end{array}$} & \multicolumn{14}{|c|}{ 310-M0008A- } \\
\hline & $\begin{array}{l}4 \mathrm{R}-1 \\
22-28\end{array}$ & $\begin{array}{l}5 \mathrm{R}-1 \\
15-20\end{array}$ & $\begin{array}{c}\text { 7R-CC, } \\
4-13\end{array}$ & $\begin{array}{l}8 \mathrm{R}-1 \\
42-51\end{array}$ & $\begin{array}{l}8 \mathrm{R}-1 \\
61-80\end{array}$ & $\begin{array}{c}\text { 9R-CC, } \\
0-5\end{array}$ & $\begin{array}{l}10 \mathrm{R}-1 \\
27-30\end{array}$ & $\begin{array}{c}14 \mathrm{R}-1, \\
0-10\end{array}$ & $\begin{array}{l}14 R-1, \\
24-28\end{array}$ & $\begin{array}{l}16 \mathrm{R}-1, \\
55-60\end{array}$ & $\begin{array}{c}\text { 16R-1, } \\
115-120\end{array}$ & $\begin{array}{c}17 \mathrm{R}-1, \\
0-5\end{array}$ & $\begin{array}{l}17 \mathrm{R}-1, \\
10-15\end{array}$ & $\begin{array}{l}17 \mathrm{R}-1, \\
18-23\end{array}$ \\
\hline Matrix: & $\begin{array}{l}\text { Gray sand/ } \\
\text { Silt }\end{array}$ & $\begin{array}{c}\text { Gray sand/ } \\
\text { Silt }\end{array}$ & Boulder (1) & Boulder (2) & Cobble & Pebble & Pebble & Pebble & $\begin{array}{c}\text { Brown } \\
\text { sand/Silt }\end{array}$ & $\begin{array}{c}\text { Brown } \\
\text { sand/Silt }\end{array}$ & $\begin{array}{l}\text { Brown clay/ } \\
\text { Sand }\end{array}$ & Pebble & Pebble & Pebble \\
\hline \multicolumn{15}{|c|}{ Major elements (wt\%): } \\
\hline $\mathrm{SiO}_{2}$ & 32.79 & 29.86 & 42.15 & 42.68 & 42.32 & 41.01 & 37.80 & 44.03 & 41.44 & 38.90 & 31.37 & 43.59 & 45.15 & 47.06 \\
\hline $\mathrm{TiO}_{2}$ & 2.97 & 2.83 & 3.15 & 3.13 & 1.77 & 3.46 & 2.90 & 4.07 & 3.22 & 3.39 & 3.84 & 3.33 & 3.69 & 3.64 \\
\hline $\mathrm{Al}_{2} \mathrm{O}_{3}$ & 13.22 & 11.92 & 15.56 & 15.83 & 8.51 & 15.87 & 9.69 & 16.50 & 12.04 & 14.80 & 13.88 & 14.85 & 14.96 & 16.66 \\
\hline $\mathrm{Fe}_{2} \mathrm{O}_{3}$ & 13.02 & 12.13 & 12.16 & 12.26 & 10.84 & 12.38 & 12.90 & 10.33 & 15.78 & 16.05 & 16.59 & 12.18 & 11.68 & 11.39 \\
\hline $\mathrm{MnO}$ & 0.15 & 0.14 & 0.16 & 0.17 & 0.17 & 0.18 & 0.17 & 0.13 & 0.16 & 0.21 & 0.36 & 0.15 & 0.16 & 0.16 \\
\hline $\mathrm{MgO}$ & 9.99 & 9.67 & 4.98 & 6.04 & 16.76 & 4.33 & 14.22 & 3.07 & 4.96 & 5.15 & 2.95 & 5.59 & 4.48 & 5.08 \\
\hline $\mathrm{CaO}$ & 7.63 & 9.12 & 9.58 & 9.98 & 12.02 & 8.96 & 9.12 & 8.89 & 1.36 & 1.60 & 1.44 & 9.37 & 7.63 & 9.98 \\
\hline $\mathrm{K}_{2} \mathrm{O}$ & 0.81 & 0.71 & 1.21 & 1.07 & 0.44 & 1.45 & 0.95 & 2.01 & 0.73 & 0.76 & 0.84 & 1.48 & 2.04 & 1.81 \\
\hline $\mathrm{P}_{2} \mathrm{O}_{5}$ & 0.30 & 0.26 & 0.69 & 0.66 & 0.14 & 0.51 & 0.25 & 0.90 & 0.05 & 0.23 & 0.32 & 0.58 & 0.88 & 0.88 \\
\hline \multicolumn{15}{|c|}{ Trace elements (mM): } \\
\hline $\mathrm{Sr}$ & 432 & 544 & 675 & 662 & 258 & 646 & 414 & 754 & 287 & 370 & 422 & 609 & 808 & 722 \\
\hline $\mathrm{Ba}$ & 100 & 211 & 398 & 319 & 125 & 503 & 320 & 750 & 288 & 279 & 324 & 361 & 523 & 480 \\
\hline $\mathrm{Rb}$ & 23.2 & 21.4 & 22.8 & 22.5 & 11.1 & 30.9 & 23.2 & 40.1 & 35.8 & 29.6 & 37.5 & 31.2 & 56.8 & 40.5 \\
\hline $\mathrm{Cu}$ & 54.1 & 61.2 & 93.9 & 88.2 & 45.2 & 113 & 67.8 & 51.1 & 51.3 & 66.0 & 70.6 & 69.1 & 72.7 & 69.0 \\
\hline $\mathrm{Ni}$ & 241 & 248 & 50.9 & 54.1 & 381 & 66.1 & 453 & 90.9 & 230 & 305 & 286 & 100 & 30.8 & 73.3 \\
\hline $\mathrm{Zn}$ & 104 & 97.0 & 95.3 & 93.6 & 67.7 & 99.3 & 98.0 & 89.3 & 113 & 124 & 122 & 103 & 120 & 116 \\
\hline$S$ & 13,250 & 15,180 & 204 & 160 & 155 & 2,496 & 176 & 423 & 468 & 538 & 407 & 125 & 107 & 333 \\
\hline $\mathrm{Cl}$ & 8,394 & 7,903 & 158 & 230 & $<2.0$ & 5,305 & 737 & 4,873 & 10,210 & 9,140 & 8,032 & 293 & 163 & 327 \\
\hline $\mathrm{Br}$ & 24.6 & 19.7 & 1.1 & 1.6 & $<1.4$ & 10.3 & $<1.6$ & 10.9 & 37.1 & 29.7 & 28.4 & 1.0 & $<1.7$ & $<1.8$ \\
\hline
\end{tabular}

Note: See Table T2 in the "Methods" chapter for elemental accuracy and precision data. 